\title{
Islamic Republic of Mauritania: Third Review Under the Three-Year Extended Credit Facility Arrangement-Staff Report; Press Release on the Executive Board Discussion.
}

In the context of the third review under the three-year Extended Credit Facility arrangement, the following documents have been released and are included in this package:

- $\quad$ The staff report for the third review under the three-year Extended Credit Facility arrangement, prepared by a staff team of the IMF, following discussions that ended on October 24, 2011, with the officials of the Islamic Republic of Mauritania on economic developments and policies. Based on information available at the time of these discussions, the staff report was completed on November 23, 2011. The views expressed in the staff report are those of the staff team and do not necessarily reflect the views of the Executive Board of the IMF.

- $\quad$ A Press Release.

The documents listed below have been or will be separately released.

Letter of Intent sent to the IMF by the authorities of Mauritania*

Technical Memorandum of Understanding by the authorities of Mauritania*

*Also included in Staff Report

The policy of publication of staff reports and other documents allows for the deletion of market-sensitive information.

Copies of this report are available to the public from

International Monetary Fund • Publication Services

$70019^{\text {th }}$ Street, N.W. $\bullet$ Washington, D.C. 20431

Telephone: (202) 623-7430 • Telefax: (202) 623-7201

E-mail: publications@imf.org Internet: http://www.imf.org

\section{International Monetary Fund Washington, D.C.}




\title{
INTERNATIONAL MONETARY FUND
}

\section{ISLAMIC REPUBLIC OF MAURITANIA}

\section{Third Review Under the Three-Year Extended Credit Facility Arrangement}

\author{
Prepared by the Middle East and Central Asia Department \\ (In consultation with other departments)
}

Approved by Alan MacArthur and Dhaneshwar Ghura

November 23, 2011

Context: Supported by high commodity prices, economic activity has been strong, the fiscal position improved, the current account deficit narrowed, and foreign exchange reserves reached record levels. Going forward, the economy needs to confront drought ramifications and risks arising from a sharp fall in external demand. Additional mining proceeds will finance the initial emergency drought relief response.

Program: All continuous and quantitative performance criteria for end-June 2011 were met. The completion of the end-October structural benchmark on the poverty survey was delayed because of logistical difficulties.

Exchange rate regime: The exchange rate is de facto classified as other managed arrangement. Mauritania has accepted the obligations of Article VIII, Sections 2-(a), 3, and 4 of the Fund's Articles of Agreement, and maintains an exchange system free of restrictions on the making of payments and transfers for current international transactions.

Discussions: The team comprised A. Mati (head), Y. Zouhar, R. Blotevogel, B. Terrier (all MCD), and C. Ebeke (SPR). T. Najeh (Resident Representative) assisted. Discussions were held in Nouakchott during October 11-24, 2011. The mission met with the President, the Governor of the Central Bank, the Minister of Finance, the Minister of Economic Affairs and Development, the Minister of Energy, the Minister of Rural Development, the Minister of Labor and Social Affairs, other senior officials, and representatives of the corporate and banking sector, diplomatic and donor community, civil society, and Parliament (including members of the opposition). 


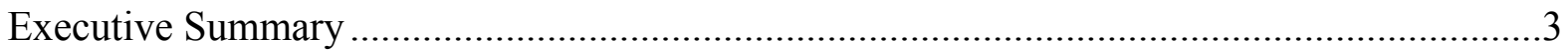

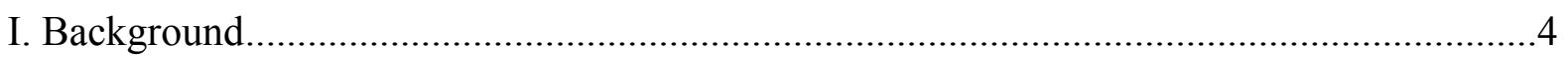

II. Recent Economic Developments and Program Implementation............................................5

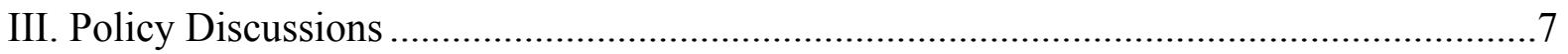

A. Macroeconomic Outlook.................................................................................

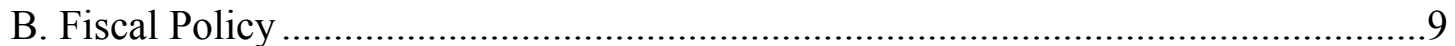

C. Monetary, Exchange Rate, and Financial Sector Policies.........................................12

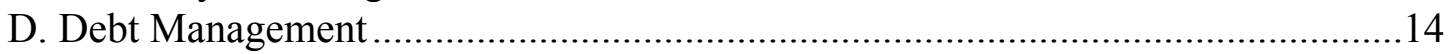

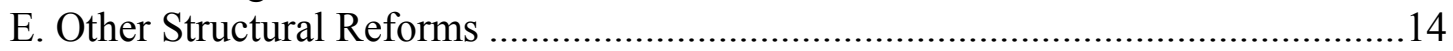

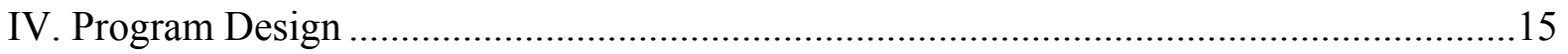

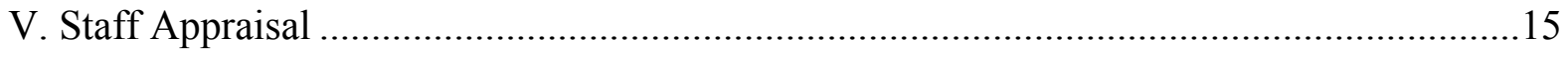

Tables

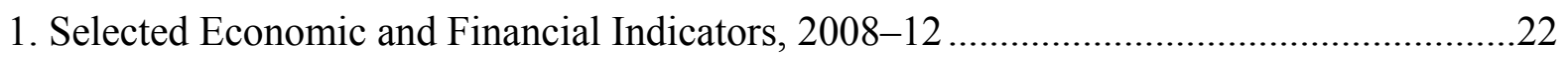

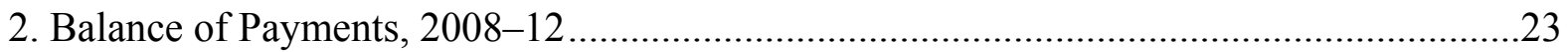

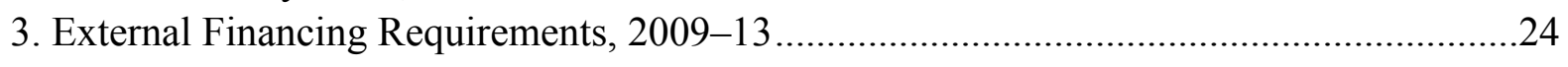

4a. Central Government Operations, 2008-12 (In billions of Ouguiyas)...............................25

4b. Central Government Operation, 2008-12 (In percent of non-oil GDP) ...........................26

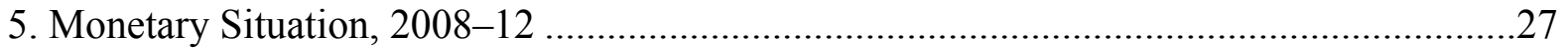

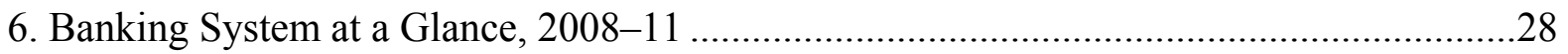

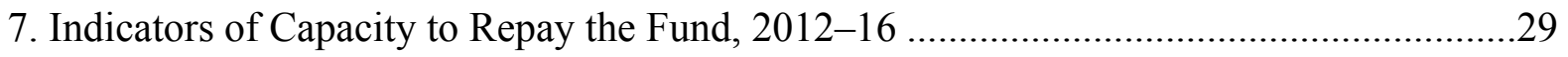

8. Selected Economic and Financial Indicators, 2008-16 …................................................

9. Access and Phasing Under the Three-Year ECF Arrangement, 2010-13 ...........................31

Figures

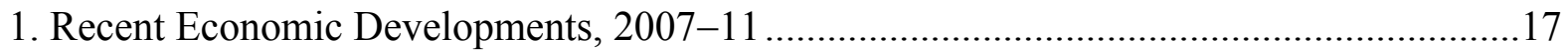

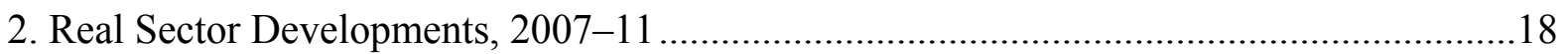

3. Selected Monetary and Financial Sector Indicators, 2007-11 .........................................19

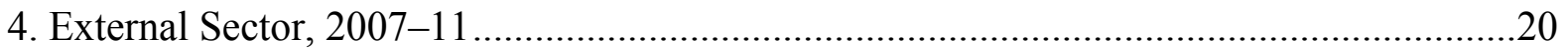

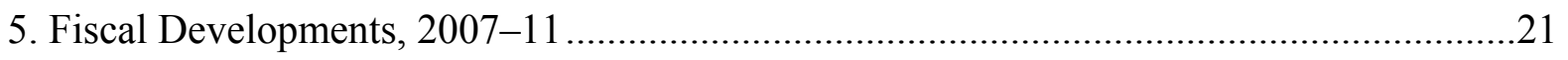

Boxes

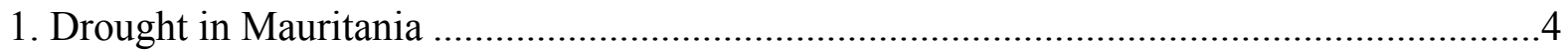

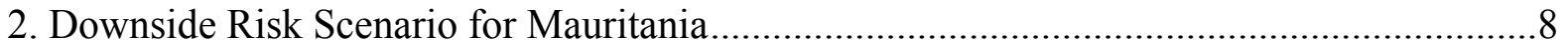

3. Mauritania's Move Toward a Comprehensive Subsidy Reform ........................................11

Attachments

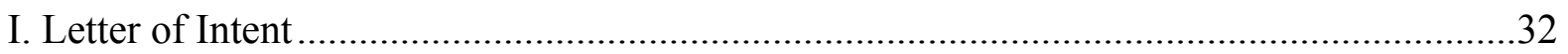

II. Technical Memorandum of Understanding....................................................................4 


\section{EXECUTIVE SUMMARY}

Macroeconomic developments have been broadly positive, despite high international fuel and food prices and the near-term drought impact. Supported by a rapid growth in manufacturing industries, non-oil output is expected to grow by 4.8 percent in 2011 despite the drought-related downturn in agricultural production. Low price pass-through and a prudent monetary policy helped contain inflation. Booming mining exports helped narrow the current account deficit and boost foreign exchange reserves to unprecedented levels.

Performance under the ECF-supported program has been strong. All continuous and quantitative performance criteria for end-June 2011-including the indicative target on poverty-related spending - were met with a comfortable margin, thanks in no small part to higher than envisaged mining proceeds. The structural reform agenda is advancing well, with the exception of the 2011 end-October structural benchmark on the poverty survey, which has been delayed to 2012 because of the rainy season and the overlap with the controversial civil census.

A severe drought and sharp fall in external demand represent significant risks. A more severe than expected drought impact or fall in commodity metals prices would significantly worsen economic indicators, despite Mauritania's build-up of external and fiscal buffers over the past year. High unemployment and poverty rates represent key remaining challenges.

\section{Continued fiscal consolidation is necessary to limit vulnerabilities and maintain} macroeconomic stability. Additional expenditures linked to the government's drought relief program are temporary, thus reducing sustainability concerns arising from fiscal policy's dependence on volatile mining revenues. The draft 2012 budget appropriately preserves fiscal discipline thanks to decisive actions on subsidy and civil service reform as well as greater revenue mobilization. Reaching agreement on the outstanding debt relief with Kuwait is critical for preserving debt sustainability.

Monetary policy remains appropriately geared towards containing inflation in a context of greater exchange rate flexibility. Inflation is expected to stay within single digits, with the $\mathrm{CBM}$ ready to tighten the monetary stance if inflationary pressures start to materialize. Resilience of the financial system will be strengthened through increased banks' capital and enhanced banking supervision.

Efforts to step up structural reforms will continue. Restructuring public enterprises, strengthening the investment climate, boosting access to credit, and enhancing the functioning of the labor market will be crucial for achieving broad-based inclusive growth. 


\section{BACKGROUND}

1. The Arab Spring has had only a minimal impact on Mauritania. Political unrest has remained sporadic, and tensions have recently centered around groups of AfricanMauritanians opposing the civil census launched earlier in the year. Measures aimed at protecting the poor from high food and energy prices and, more recently, an increase in the minimum wage have helped ease social tensions. A newly signed agreement between opposition leaders and government calls for the creation of an independent electoral commission and more media liberalization, which are expected to be in place ahead of next year's municipal and legislative elections.

2. Mauritania is facing a serious drought. While a full evaluation is still outstanding, many NGOs and multilateral organizations consider the situation dire (Box 1). Immediate needs linked to free food distribution and the procurement of livestock feeds will have to be met in early 2012. Additional external funds will be needed if the drought impact turns out to be more severe than expected.

\section{Box 1. Drought in Mauritania}

Early warning signs point to a severe drought impact in Mauritania. Approximately 90 percent of the rainfall gauging stations have shown significant deficits and dams are less than 50 percent full. Such a situation is reminiscent of 2002, a harsh drought year in Mauritania. Initial field missions conducted by the authorities and donors indicate a 60-70 percent decline in cultivated areas, which will cause a 50 percent drop in cereal production. The ensuing shrinkage in available pastures will also drastically reduce livestock - the main productive asset for most of the rural population — which is already being sold in some areas at depressed prices.

The considerable economic loss for the rural population will significantly increase food insecurity, particularly among the poor. The World Food Program (WFP)'s preliminary estimates indicate that the number of persons living in food insecurity doubled to at least 700,000 people in September 2011 and could increase to as many as 900,000 people by early 2012 (a quarter of Mauritania's population). Most of that impact will be felt by the poor as subsistence farming and livestock provide for at least 20 percent of their food intake.

An initial emergency program has been prepared to address the emerging food crisis situation, but full donor mobilization will require an emergency declaration. An emergency response programestimated at $\$ 90$ million - is being finalized for incorporation into the 2012 budget. This initial response is aimed at dealing with the most pressing needs, including food distribution in affected areas. This needs to be supplemented by a rapid and coordinated response from donors. The preparation for additional donor financing - including such measures as bringing forward and scaling up existing aid programs - is underway. However, the government is still appraising the full cost of the drought impact, and is not yet in a position to declare a state of emergency, which is necessary to fully mobilize additional external assistance. Delays in declaring an emergency may limit resources available to Mauritania, as it could face donor fatigue from ongoing relief efforts in the Horn of Africa and neighboring countries (Mali, Niger). 


\section{Significant progress under the ECF-supported arrangement notwithstanding,} Mauritania still faces several long-standing challenges. Widespread poverty and unemployment, poor infrastructure, and inadequate supply of medium- and long-term financing hamper efforts to diversify the economy and weigh on private-sector activity. The economy has only limited buffers to cushion external shocks arising from a sharp drop in metals prices or shortfall in donor funding.

\section{ReCENT ECONOMIC DEVELOPMENTS AND PROGRAM IMPLEMENTATION}

\section{Macroeconomic performance was resilient, despite high international food and} fuel prices and the near-term drought impact (Tables 1-8, Figures 1-5):

- $\quad$ Economic activity expanded at a rapid pace in the first half of 2011, supported by rapid growth in manufacturing industries (the production index of non-extractive industries was up by 16 percent y-o-y), and higher mining and public investments. Full-year real GDP is set to grow by 4.8 percent in 2011, slightly less than programmed, because of a severe decline in agricultural and livestock production (about 15 percent of economic activity) and some slowdown in iron ore production.
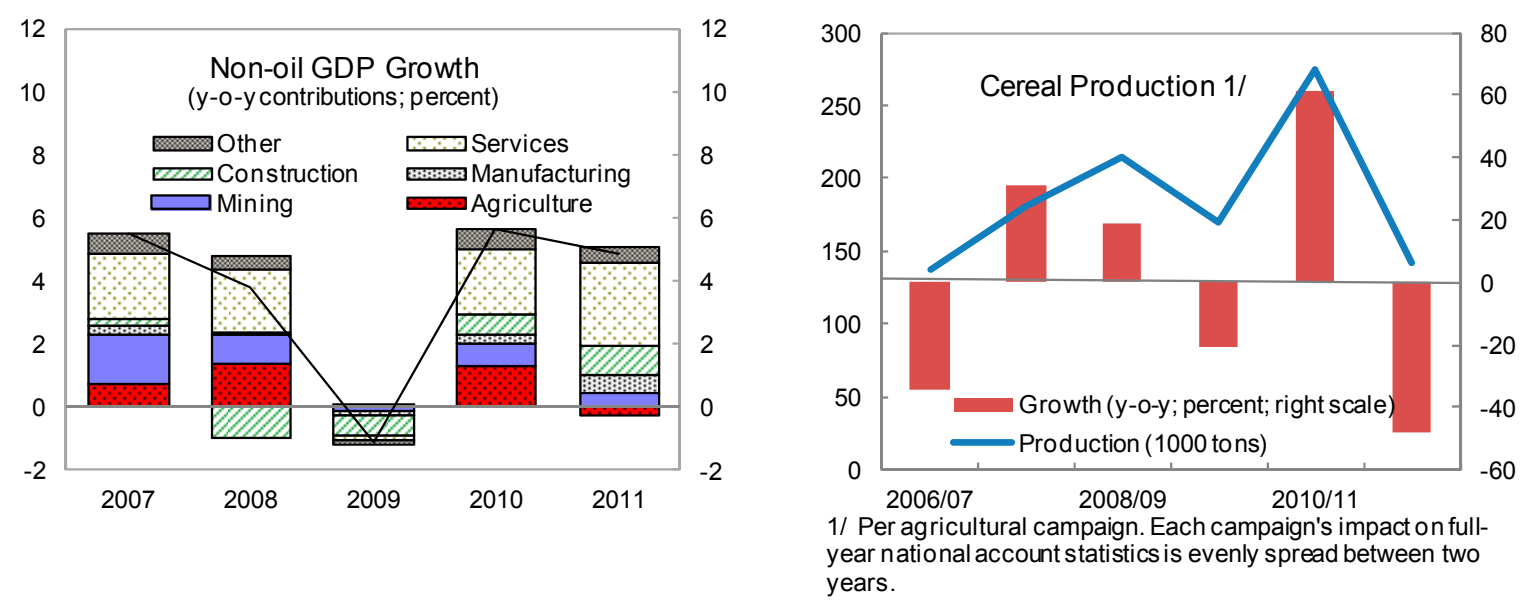

- $\quad$ Headline inflation moderated to 5.4 percent (y-o-y) by end-June as widespread use of administered prices dampened pass-through from international food (22 percent in the 12 months to June 2011) and energy prices (16 percent). Moreover, connected lending and severe information asymmetries have hampered financial intermediation, thus preventing rapid money growth (24.9 percent y-o-y in June) from fuelling a credit boom. However, inflation rose to 6.1 percent y-o-y in September and is expected to increase further in the next few months because of administered price hikes.

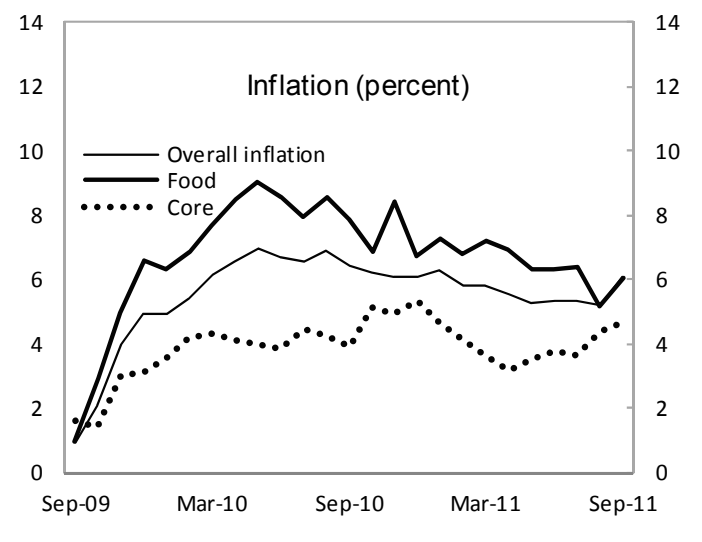



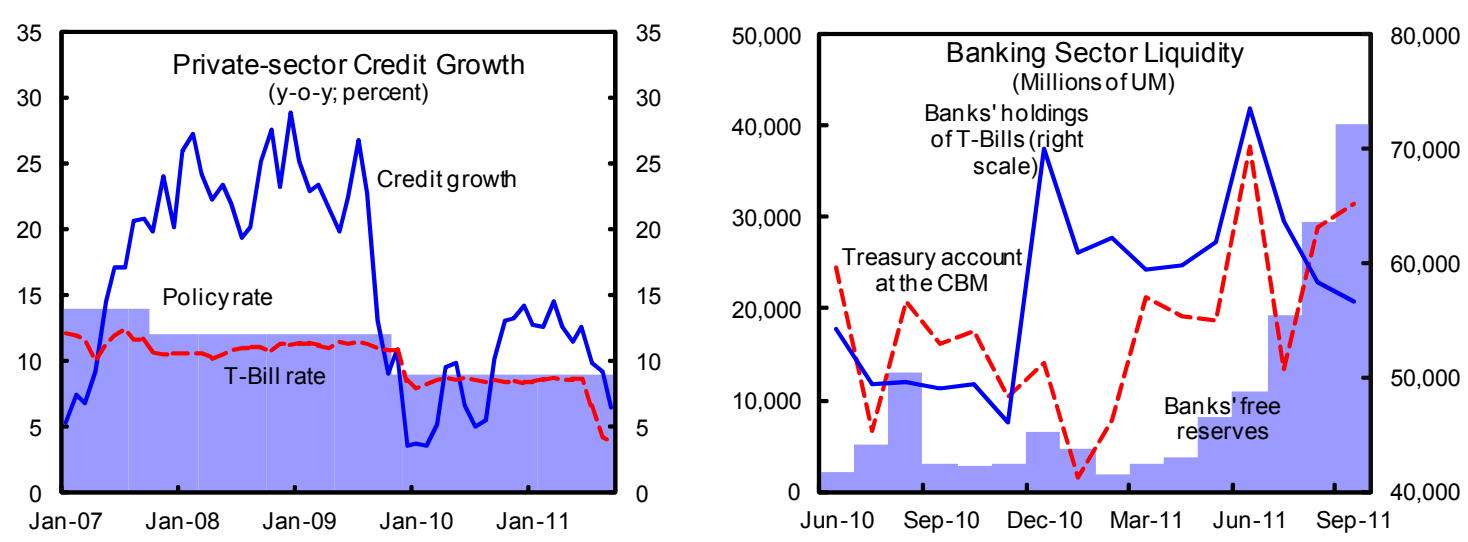

- The external current account deficit narrowed significantly, and is expected to reach 5.3 percent of GDP by end-year as near-record prices for key metal exports more than offset swelling food and energy imports. Meanwhile, on the back of continued strong inflows of FDI (14 percent of GDP) and foreign loans (6 percent of GDP), international reserves rose to an unprecedented $\$ 522$ million in September, and are expected to stabilize by end-year at around $\$ 445$ million (about 3.6 months of imports).

- $\quad$ Higher mining revenues — combined with significant payment delays on energy subsidies that were not initially budgeted for-led to a record accumulation of government deposits and a better cash fiscal position $(0.5$ percentage point of

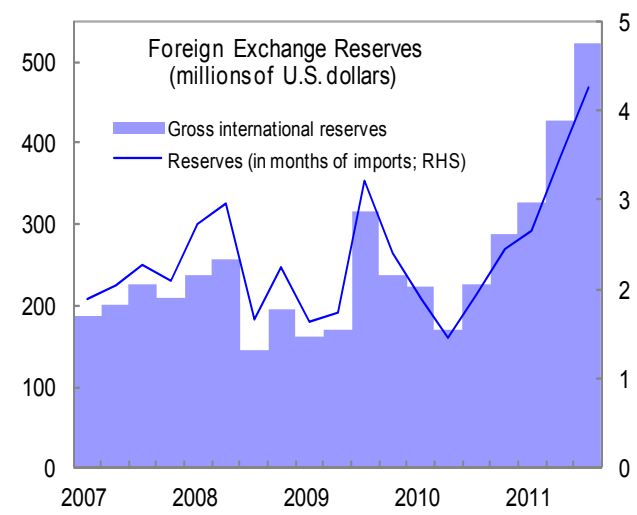
GDP higher than programmed at end-June). The government has since started to draw down its comfortable cash balance, reducing the stock of outstanding T-bills in the process, and causing T-bill yields to fall to an all-time low of 2.75 percent in October 2011. The ongoing seasonal acceleration of investment spending and the timely disbursement of all payments due in 2011 is expected to somewhat reverse the decline in yields, although the non-oil basic fiscal deficit will still be about 0.6 percentage point of non-oil GDP better than programmed.

5. Program implementation has been strong. All continuous and quantitative performance criteria for end-June 2011 were met (LOI, Table 1). The structural reform agenda is advancing well, with the exception of the 2011 end-October structural benchmark on the poverty survey, which has been delayed because of the rainy season and overlap with the controversial civil census (LOI 93 , and Table 2a). 


\section{Policy Discussions}

\section{A. Macroeconomic Outlook}

6. The outlook for $\mathbf{2 0 1 2}$ remains generally favorable. Real GDP growth is projected to reach 5.5 percent, driven by higher manufacturing activity and the ongoing expansion of mining capacity (particularly gold), which more than offset the drought-related downturn of the agricultural sector. Inflation is expected to stabilize slightly below 7 percent as the authorities are committed to preventing second-round effects from increases in administered prices. Higher costs for food imports (a 35 percent volume increase, mostly because of the drought) and foreign-financed mining investment projects will widen the current account deficit in spite of the ongoing improvements in mining production and elevated metals prices. ${ }^{1}$ However, mining-related FDI and concessional lending will further improve the overall balance of payments, thus pushing gross foreign reserves to $\$ 514$ million, about 4.2 months of imports.

Main Macroeconomic Indicators, 2008-12

(Percent; unless otherw ise indicated)

\begin{tabular}{lrrrrr}
\hline & 2008 & 2009 & 2010 & 2011 & 2012 \\
& & & Est. & Proj. & Proj. \\
\hline Real GDP growth & 3.5 & -1.2 & 5.2 & 4.8 & 5.5 \\
Real GDP growth excluding extractive industries & 3.4 & -1.1 & 5.7 & 5.1 & 5.0 \\
Inflation, end-of-period & 3.9 & 5.0 & 6.1 & 6.7 & 6.8 \\
Current account balance (percent of GDP) & -14.8 & -10.7 & -8.8 & -5.3 & -7.2 \\
Gross official reserves 1/ & 2.1 & 2.6 & 2.5 & 3.6 & 4.2 \\
\hline
\end{tabular}

Sources: Mauritanian authorities; and Fund staff estimates.

$1 /$ In months of following year's imports excluding extractive industries.

7. Risks are mostly skewed to the downside. Mauritania's ability to cushion the fallout from a sharp drop in external demand and metals prices is limited (see Box 2). The outlook for Europe, Mauritania's largest trading partner, is increasingly uncertain, and international prices for iron ore have recently become more volatile. In addition, the drought could turn out to be more severe than currently estimated, thereby worsening growth prospects. As for upside risks, a stronger-than-expected implementation of the reform agenda, lower food and energy prices (coinciding with still-elevated metals prices), and additional donor support could lead to more economic dynamism than currently expected.

\footnotetext{
${ }^{1}$ Despite higher food imports, total imports in 2012 are lower than programmed in CR/11/189 due to a downward revision of other imports such as garments, cars, and construction materials.
} 


\section{Box 2. Downside Risk Scenario for Mauritania}

The downside risk scenario for Mauritania focuses on a sharp fall in global demand caused by turmoil in Europe. The resulting severe commodity metal price collapse significantly affects Mauritania's economy, although increased fiscal and external buffers built in 2011 allow for greater resilience than in the 2008-09 crisis.

Key external vulnerabilities: Mauritania's export base is narrow, with mining and fish accounting for 80 percent of total exports, which are mostly sold to China and Europe. This export concentration, combined with the country's dependence on foreign aid ( 9 percent of GDP), exposes the country to terms-of-trade shocks and recessions in donor countries.

Main Scenario Assumptions:

(i) drop in metals prices consistent with the initial 2008-09 crisis (40 percent for iron ore, and 15 percent for gold and copper); (ii) 25 percent decline in petroleum prices (a deviation from historical

\begin{tabular}{lcc}
\multicolumn{2}{c}{ Impact of Reversal in Commodities Prices and External Demand in 2012} \\
\hline & $\begin{array}{c}\text { Adverse } \\
\text { scenario }\end{array}$ & $\begin{array}{c}\text { Difference with } \\
\text { Respect to the } \\
2012 \text { Baseline }\end{array}$ \\
\hline & 2.2 & -3.3 \\
\hline Real and monetary sectors & 7.6 & -4.8 \\
$\quad$ Real GDP growth (percent) & 4.2 & -2.6 \\
Private-sector credit growth (percent) & & \\
CPI inflation (period average; percent) & -3.0 & -2.3 \\
Fiscal sector & -6.3 & -2.9 \\
Basic non-oil balance (percent of non-oil GDP); program definition 1/ & 11.4 \\
Overall balance (percent non-oil GDP) & 70.2 & \\
Public debt (percent of GDP) & & -11.5 \\
External sector & -18.6 & 9.0 \\
Current account balance (percent of GDP) & 60.9 & -219.1 \\
PPG external debt (percent of GDP) & 410.7 & -0.8 \\
SNIM accumulation of foreign deposits (millions of U.S. dollars) & 10.3 & -1.0 \\
International reserves & 3.2 & -116.2 \\
$\quad$ Percent of GDP & 397.4 & \\
$\quad$ Months of prospective imports & & \\
Millions of U.S. dollars & & \\
\hline
\end{tabular}

$1 /$ Detined as government non-oil revenue (excluding grants) minus government expenditure (excluding toreignfinanced investment expenditure and interest on external debt). patterns where petroleum and iron ore price changes were highly correlated) while food prices remain high; and (iii) a 30 and 10 percent decline in main trading partners' demand for iron ore and fish, respectively.

\section{All sectors of the economy are affected:}

- The decline in iron ore production - consistent with European clients declaring a case of force majeure and reneging on contracts as was the case in 2009-lowers real GDP to about 2 percent. Inflation will also decline as a result of falling energy prices and weaker domestic demand.

- $\quad$ The fall in economic activity, combined with lower mining revenues, ${ }^{1}$ will widen the overall fiscal deficit by about 3 percent of GDP. This will be mostly financed by T-bills and a drawdown in treasury balances.

- The current account deficit will widen significantly following a 30 percent drop in exports that was only partly compensated by a drop in oil imports. The resulting 11 percent of GDP widening would have been smaller if oil prices had declined by more (as was the case in 2009 when they fully compensated for the drop in iron ore exports). The ensuing financing gap is covered by a loss in reserves and less accumulation of SNIM's fx deposits abroad. Total external debt will rise to 60 percent of GDP.

- $\quad$ The banking system would be relatively unaffected in view of its relatively low degree of financial integration vis-à-vis the rest of the world. Indeed, Mauritanian banks are mainly involved in trade finance via letters of credit and banks overwhelming fund themselves domestically, with 90 percent of all liabilities held by residents. However, the decline in economic activity is likely to compress private-sector credit further and declining fx inflows may trigger rationing by the central bank, affecting bank profitability and liquidity.

\footnotetext{
${ }^{1 /}$ Staff assumes that the national mining company (SNIM) will renegotiate the dividend payout ratio agreed in the 2012 budget.
} 


\section{Box 2. Downside Risk Scenario for Mauritania (concluded)}

- That said, the economy is more resilient than in the past, with some key economic indicators remaining at higher levels than in past pre-crisis episodes because of Mauritania's ability to build buffers during the 2010-11 recovery (contrary to developments observed in many oil importers since the global crisis).

Comparison of Pre-Crisis Buffers in 2007 and 2011
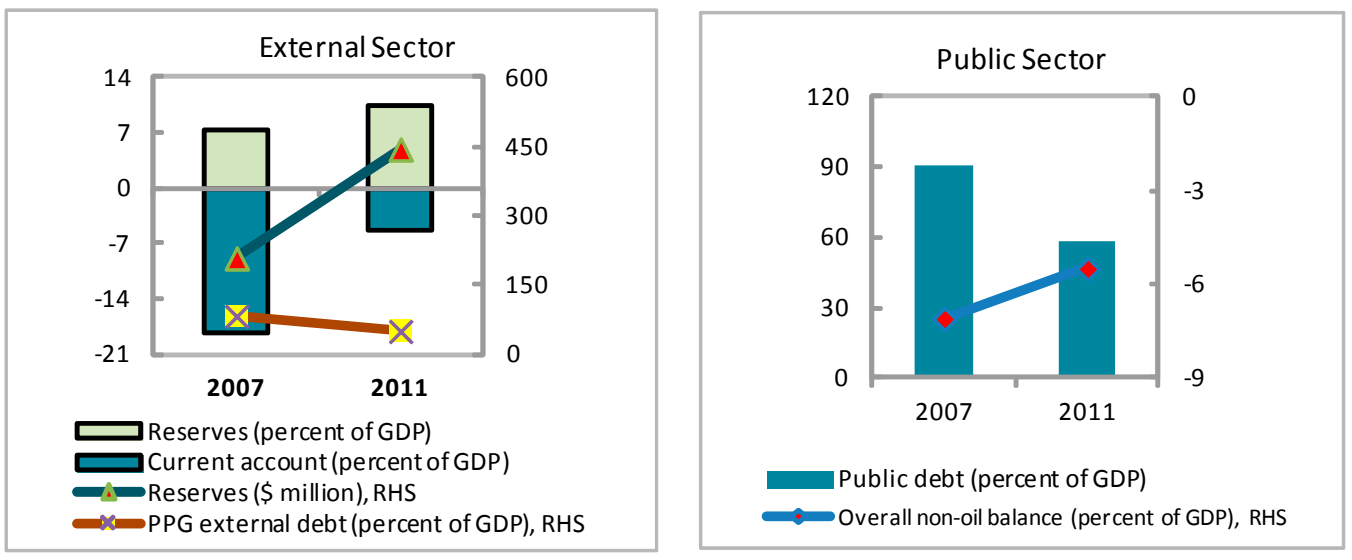

Source: Mauritanian authorities; and Fund staff estimates.

\section{B. Fiscal Policy}

8. The emergency program aimed at mitigating the impact of the drought is a key element of the 2012 budget. The mission stressed the importance of drafting a realistic budget that takes into account increased expenditures associated with the drought relief program - mostly increased free food distribution in rural areas and subsidies for livestock feeds - which are expected to cost about 2 percent of GDP. The authorities agreed that

\begin{tabular}{|c|c|c|}
\hline \multicolumn{3}{|c|}{$\begin{array}{l}\text { Drought Emergency Response in } 2003 \text { and } 2012 \\
\text { (In billions of ouguiya; unless otherwise specified) }\end{array}$} \\
\hline & 2003 & 2012 \\
\hline 1. Preventing food insecurity & 6.9 & 12 \\
\hline Free food distribution & 4.9 & 2.5 \\
\hline Subsidized food & 2.0 & 7.0 \\
\hline Cash transfer & & 2.5 \\
\hline Replenishing food security stocks $1 /$ & & .. \\
\hline 2. Providing health care for vulnerable groups and children $1 /$ & 0.8 & .. \\
\hline 3. Preserving livestock & 1.5 & 11.2 \\
\hline 4. Developing income generating activities & 1.0 & \\
\hline 5. Monitoring and supervision & 0.3 & \\
\hline Total (initial estimate) & 10.6 & 23.2 \\
\hline Final cost & 20.1 & \\
\hline in percent of non-oil GDP & 6.9 & 2.0 \\
\hline
\end{tabular}
such budgeting will help prioritize spending, avoid payment delays associated with the adoption of emergency decrees, and improve budget transparency and accountability.

9. Fiscal consolidation remains a top priority for 2012. The authorities remain committed to program consolidation objectives, with the non-oil basic deficit projected to improve to 0.7 percent of GDP (LOI, $\uparrow 11-13$ ) as a result of: 
- Improved revenue mobilization: The government agreed to increase the dividend pay-out ratio on the record profit expected from the public mining company (SNIM) in 2011 and reestablish excises on tobacco (LOI, $\$ 12)$. Implementation of deeper tax reforms - issuance of single-taxpayer identification codes (end-2011 structural benchmark), better linkages of databases between tax and customs administration, and full implementation of ASYCUDA ++- will further enhance tax collection.

- Subsidy reform: Savings of about 1.2 percent of GDP will be achieved through the ongoing phasing out of ill-targeted energy subsidies, with diesel prices expected to reach international prices by end-year (Box 3, LOIף13 and 22). Subsidy removal will be accompanied by the scaling-up of well-targeted cash transfer schemes for the neediest, based on the results of the poverty and vulnerability studies expected to be completed for Nouakchott (by end-year) and rest of the country (April 2012). An evaluation of the existing food subsidy schemes by end-2011 will also help design well-targeted and more cost-effective food schemes next year. Staff encouraged the authorities to step up their public information campaign to better explain the rationale for subsidy reform.

- Wage bill containment: The recent increase in the minimum wage is expected to have a negligible effect on the wage bill as it only affects temporary public sector employees ( 8 percent of the workforce). That said, the authorities acknowledged that civil service reform has been lagging and needs to be accelerated to generate meaningful savings. Consequently, they decided to update the payroll file by using the results of the civil service census and launch organizational audits of line ministries. Hiring outside the regular recruitment process will continue to be banned. Moreover, a centralized database of public enterprise employees will be established to allow for a better monitoring of their wage bill.

- Public enterprise reform: The end-2011 results of financial and technical audits of the large state-owned enterprises (end-December structural benchmark) will help lay out a viable long-term strategy for them. The audits will also feed into restructuring plans for public enterprises and establishment of performance contracts, which is essential for reducing budgetary transfers and improving public service quality. 


\section{Box 3. Mauritania's Move Toward a Comprehensive Subsidy Reform}

Rationale: Higher international petroleum prices led to an unsustainable increase in subsidies, which doubled to 5.5 percent of GDP in 2011. The government also recognizes that subsidizing energy products as part of a social safety net is a flawed strategy because such subsidies mostly benefit the rich (the poorest households spend less than two percent of total spending on energy products).
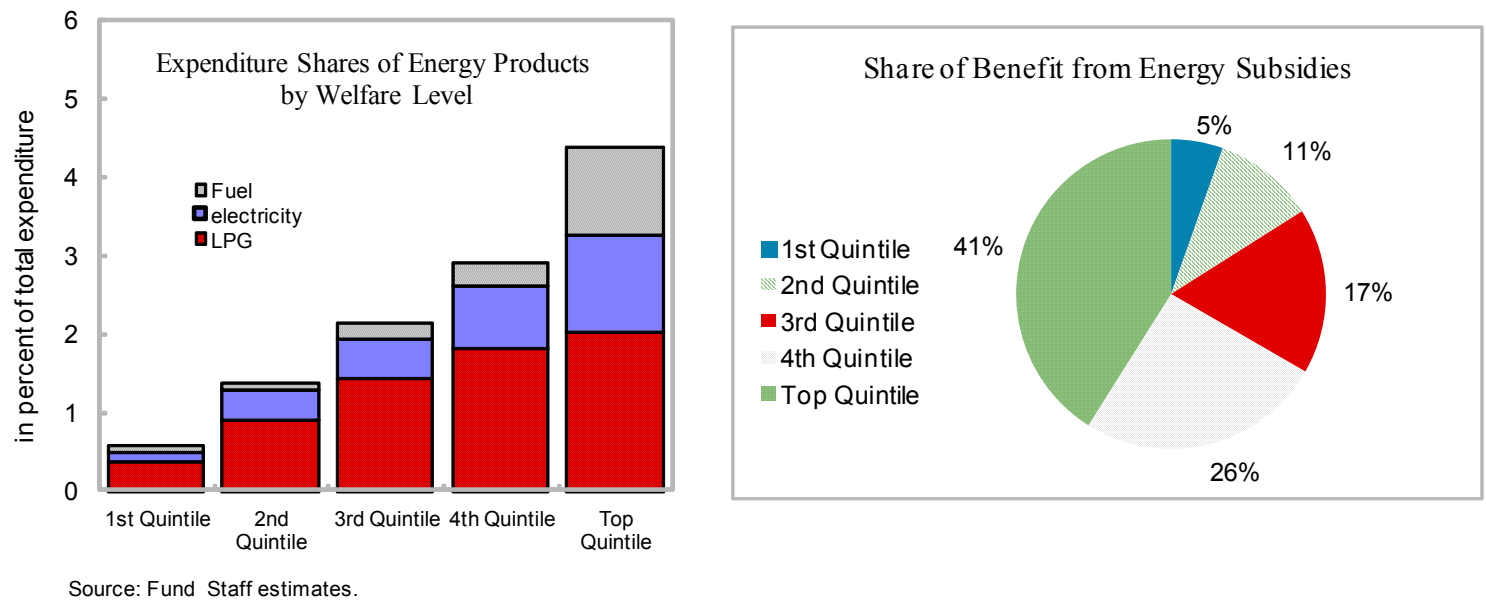

Progress so far: Gasoline prices are not subsidized. Since April 2011, diesel prices have been increased substantially, and have contributed to reducing the gap between international and domestic fuel prices to only 7.4 percent (from 30 percent). LPG prices were increased by 10 percent but remain 60 percent below international prices. Electricity tariffs have not been modified in the last four years, and remain 30 percent below cost recovery.

\section{Next steps for the strategy:}

- Diesel products: (i) Large consumers are to be excluded from the subsidized price structure; (ii) diesel prices will reach international prices in early 2012 following additional upward price adjustments in the last quarter of 2011. Following FAD recommendations, an automatic pricing formula based on a cap of price changes will be implemented to allay the authorities' concerns about large swings, and to introduce a more robust mechanism.

- LPG products: Further price hikes are expected in 2012, with additional savings to materialize from excluding large consumers.

- Electricity: The ongoing electricity tariff study should help develop a tariff grid that converges, on average, toward cost recovery prices while allowing adequately for lifeline tariffs (increasing block tariffs). Increases in electricity tariffs, particularly for large consumers, are programmed for mid-year.

\section{Accompanying elements of the strategy:}

- A full information outreach campaign will be launched to explain the subsidy reform and the need to raise energy prices. Transparent reporting on the use of freed-up budget resources should increase public confidence in the outcome of the reform.

- Social safety nets are being strengthened through scaling up of existing cash transfer schemes, free food distribution to the most vulnerable (particularly in rural areas), extension of existing school meal systems. The completion of ongoing vulnerability studies and the evaluation of the targeting performance of past programs will increase the effectiveness of existing targeting mechanisms and allow for adequate identification of the neediest beneficiaries. 
- $\quad$ Enhanced Public financial management (LOI $926-28$ ). Limiting the use of treasury advances and finalizing the transition towards a Treasury Single Account (end-December structural benchmark) will further improve budget control, execution, and transparency. Moreover, there was common agreement between staff and the authorities on fully paying any arrears accumulated in 2011 and avoiding new accumulation, with the exception of debt payments owed to the central bank, which had stopped pending Parliament approval of the protocol between the government and the central bank. A full inventory of central government domestic debt, including debt to the central bank, will be completed by end-March 2012 (structural benchmark). In the meantime, the government agreed to repay known arrears (VAT refunds and pre-2011 energy subsidies). A plan to repay arrears in the electricity sector within three years will be developed by end-year (structural benchmark, LOI 932 ).

10. The authorities concurred with the mission's view that fiscal policy remains too dependent on volatile mining revenues. They stressed that the drought relief program includes temporary and reversible measures, which do not need to be financed through permanent tax revenues. To better monitor vulnerabilities and safeguard fiscal buffers, they agreed to monitor the fiscal balance - excluding extractive industries - and establish a mining fund. Moreover, an inter-ministerial committee has been formed to fully assess the impact of the drought on the economy and monitor the relief program. It is expected that any costs additional to the budgeted amount will be financed through new donor grants, which are likely to materialize provided a formal declaration of humanitarian disaster is made. In the event of a revenue shortfall, the authorities are committed to cut nonessential spending to meet the fiscal deficit objective.

\section{Monetary, Exchange Rate, and Financial Sector Policies}

11. Monetary policy remains geared towards containing inflation in the context of a flexible exchange rate (LOI, $\mid 14-17)$ :

- $\quad$ The CBM will maintain the current monetary policy stance, but stands ready to react to any inflationary pressures. The CBM agreed on the need to tighten monetary policy if inflationary pressures materialize from exchange rate depreciation or subsidy phase-out. Similarly, the CBM indicated that it will increase the required reserve ratio if excess liquidity in the banking sector is structural and leads to a sustained surge in credit.

- The CBM is planning to reinforce its operational autonomy through the development of more flexible liquidity management tools. The most common operational framework used in the past to drain excess liquidity involved the Treasury issuing T-bills in excess of its own financing requirements. A Fund 
technical assistance mission will visit Nouakchott in the beginning of next year to help design a new framework. In the interim and in line with past Fund TA advice, the CBM will, if necessary, mop up excess liquidity by asking the Treasury to issue T-bills for monetary purposes. The Treasury, in turn, will shift all costs associated with this issuance to the CBM. The authorities agreed with staff that close coordination between fiscal and monetary policy through regular weekly meetings remains necessary.

- The CBM is committed to greater exchange rate flexibility. It argued that the ouguiya's recent depreciation is in line with fundamentals, marked by foreign reserve accumulation and higher food and energy imports. The insignificant premium in the parallel market implies a more effective functioning of the official foreign exchange market, although auction market efficiency and transparency

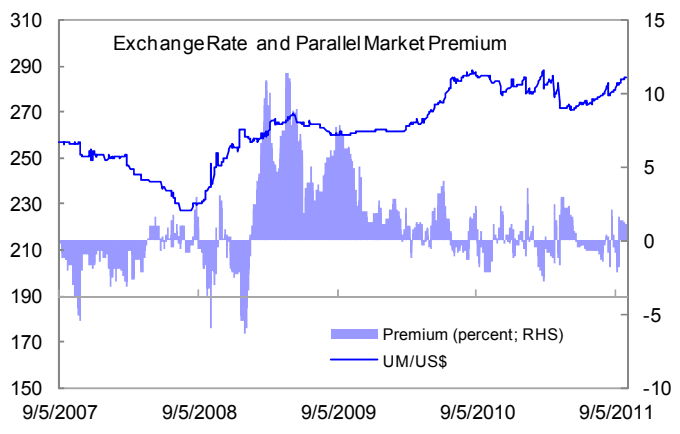
could be further improved by: (a) avoiding any off-market sales of foreign exchange; (b) regularly delivering foreign exchange purchased during auctions no later than the following day; and (c) limiting interventions to smoothing excessive fluctuations.

\section{The authorities pledged to accelerate financial sector reforms in 2012, which} may turn out to be a challenging year for the banking system. The authorities agreed to remain vigilant against risks posed by the downward pressure on banks' profitability resulting from the decline in T-Bill yields. Encouragingly, mobilizing longer-term resources to allow banks to increase the duration of loan portfolios will be part of their response. The mission urged greater efforts in improving banks' resilience through further increases in bank capital, a comprehensive audit of banks' financial position by international firms, a strict application of sanctions for breach of prudential norms, a rigorous and uniform on-site supervision process, and a review of connected lending norms (structural benchmark). Concurrently, the authorities are elaborating a financial sector strategy with World Bank assistance, which will help set priorities for the non-bank financial sector.

\section{The CBM will continue improving the transparency and accountability of its} operations. Following recommendations of the 2010 Safeguards Assessment, it will move towards adopting IFRS standards by end-2012. An important milestone in this area will be the quantification with the help of an international accounting firm of the impact of IFRS standards on the 2010 financial statements, by end-March 2012 (structural benchmark). Moreover, the CBM's accounts and program targets will continue to be audited by an international firm, another key safeguards assessment recommendation. 


\section{Debt Management}

\section{A cautious borrowing strategy and improved debt management are necessary} to ensure medium-term fiscal sustainability. Two-thirds of the $\$ 3.2$ billion donor pledges announced in Brussels for 2011-15 have now been confirmed, although greater donor mobilization may be needed to meet the country's large investment needs and finance additional drought relief. The authorities will continue to rely on concessional loans to fill their financing needs, with the exception of the nonconcessional borrowing for an electricity generation plant that was agreed at the time of the Second Review.

\section{The authorities are making their best efforts to conclude bilateral debt} restructuring discussions with Kuwait (LOI, \19). However, failure to obtain full debt relief is likely to result in a change in Mauritania's debt risk status from Moderate to High, which would affect the country's eligibility for some international donor assistance.

\section{E. Other Structural Reforms}

16. Addressing structural bottlenecks is vital for generating broad-based inclusive growth, promoting employment, and reducing poverty. Measures include:

- Boosting private-sector growth. The forthcoming adoption of the new investment code, the establishment of a one-stop shop for opening and closing enterprises, as well as measures linked to the implementation of the new procurement code, all aim at increasing investment. Staff stressed that improving the investment climate requires further progress in streamlining regulations and boosting access to credit for SMEs. The mission also urged greater efforts in developing agriculture, a sector where high unemployment is likely to rise further in the drought aftermath. It welcomed plans to provide high quality seeds to farmers, further develop irrigated systems, improve distribution networks, and upgrade infrastructure (LOI, $\llbracket 33$ ).

- Deeper labor market reforms. Staff welcomed the authorities' decision to avoid quick-fix solutions that would lead to the creation of unnecessary jobs in the public sector. Instead, the authorities chose to focus on the introduction of new professional training programs for the young and unemployed, including in the rural and fisheries sector and for people with no marketable experience. Such programs are however not enough to create jobs

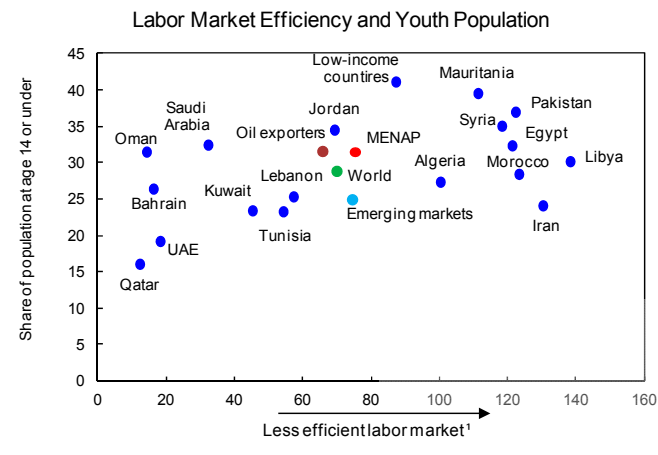

Sources: World Economic Forum, Global Competitiveness Report2010-2011 and World Bank, World Development Indicators 2009 Includes cooperation in labor-em ployer relations, flexibility in wage determination, rigidity of em ployment, hiring and firing practices, redundancy costs, pay and productivity, and reliance on professional management 
for all new labor market entrants (LOI, $\mid 34)$.

- $\quad$ Reforming the electricity sector, by pursuing the restructuring plan of the national electricity company and increasing electricity supply through new power plants (LOI, $₫ 31-32$ ).

17. The authorities will continue improving transparency and economic statistics. Staff welcomed Mauritania's coming into full compliance with the Extractive Industries Transparency Initiative (EITI) by the end of this year and the authorities' desire to move towards EITI++ (LOI, $\mid 35)$. It also encouraged the authorities to continue improving economic data provision through the construction of a new price index, updated employment and household surveys, and a quicker move toward international statistical standards (particularly for its balance of payments and national account statistics).

\section{Program Design}

18. Program design and monitoring will remain broadly unchanged. Performance criteria have been established for end-June 2012 (Attachment I, Table 1). New benchmarks for end-2011 and 2012 focus on the following macro-critical areas: public financial management, subsidy reform, banking supervision, and CBM transparency and accounting (Attachment I, Table 2b).

\section{Staff Appraisal}

19. Mauritania's macroeconomic performance continues to be strong. Economic activity has been resilient, although the country now confronts severe drought ramifications. Inflation was contained, and the fiscal and external positions have improved, creating space for a surge in reserves, and a record decline in government borrowing.

20. Nonetheless, Mauritania is facing a severe drought, and vulnerabilities remain. The outlook for 2012 - particularly the current account deficit-remains highly vulnerable to a sharp fall in external demand or more severe than expected drought impact, which may require additional external funds. More generally, growth is not sufficiently broad-based to reduce unemployment and poverty, especially in rural areas, where both remain high.

\section{Continued fiscal consolidation will help maintain stability and reduce}

vulnerabilities. The draft 2012 budget appropriately preserves fiscal discipline while allowing for drought relief expenditures and protecting much needed investment spending. Decisive actions on subsidy and civil service reform as well as greater revenue mobilization will create additional fiscal space, which will help reduce fiscal policy's reliance on volatile mining revenues. The planned evaluation of food subsidy schemes, the completion of new vulnerability studies, and the scaling up of cash transfer schemes will facilitate the introduction of well-targeted and more cost-effective social safety nets. 
22. Monetary policy remains appropriately geared towards containing inflation.

The CBM should remain vigilant and respond appropriately, with higher reserve requirements, among other measures, if inflationary pressures start to materialize. Developing a flexible liquidity management tool is essential to enhance central bank autonomy and the effectiveness of monetary policy. Boosting banks' capital and enhancing banking supervision are necessary to further strengthen banks' resilience. Further progress towards adopting IFRS accounting standards will significantly improve central bank transparency.

23. Sustaining greater exchange rate flexibility is essential to absorb external shocks. Further improvements in the foreign exchange auction market and limiting CBM interventions to smoothing excessive fluctuations are essential to provide appropriate market signals and continue building reserve buffers.

24. Concessional financing and debt relief are critical for preserving debt sustainability. Reaching agreement on outstanding debt relief will help maintain Mauritania's debt risk status as moderate.

\section{Progress on structural reforms will support employment and growth}

objectives. The implementation of the new investment and procurement codes, new agricultural development programs, and reforms of public enterprises are welcome. Reinvigorating labor market reforms and improving the business climate are essential to secure long-term broad-based inclusive growth.

26. Staff recommends completing the third review under the ECF, in light of the strong performance through end-June 2011 and the authorities' strong commitment to the program. Staff supports the establishment of new PCs for end-June 2012. 
Figure 1. Mauritania: Recent Economic Developments, 2007-11 (Percent, unless otherwise indicated)
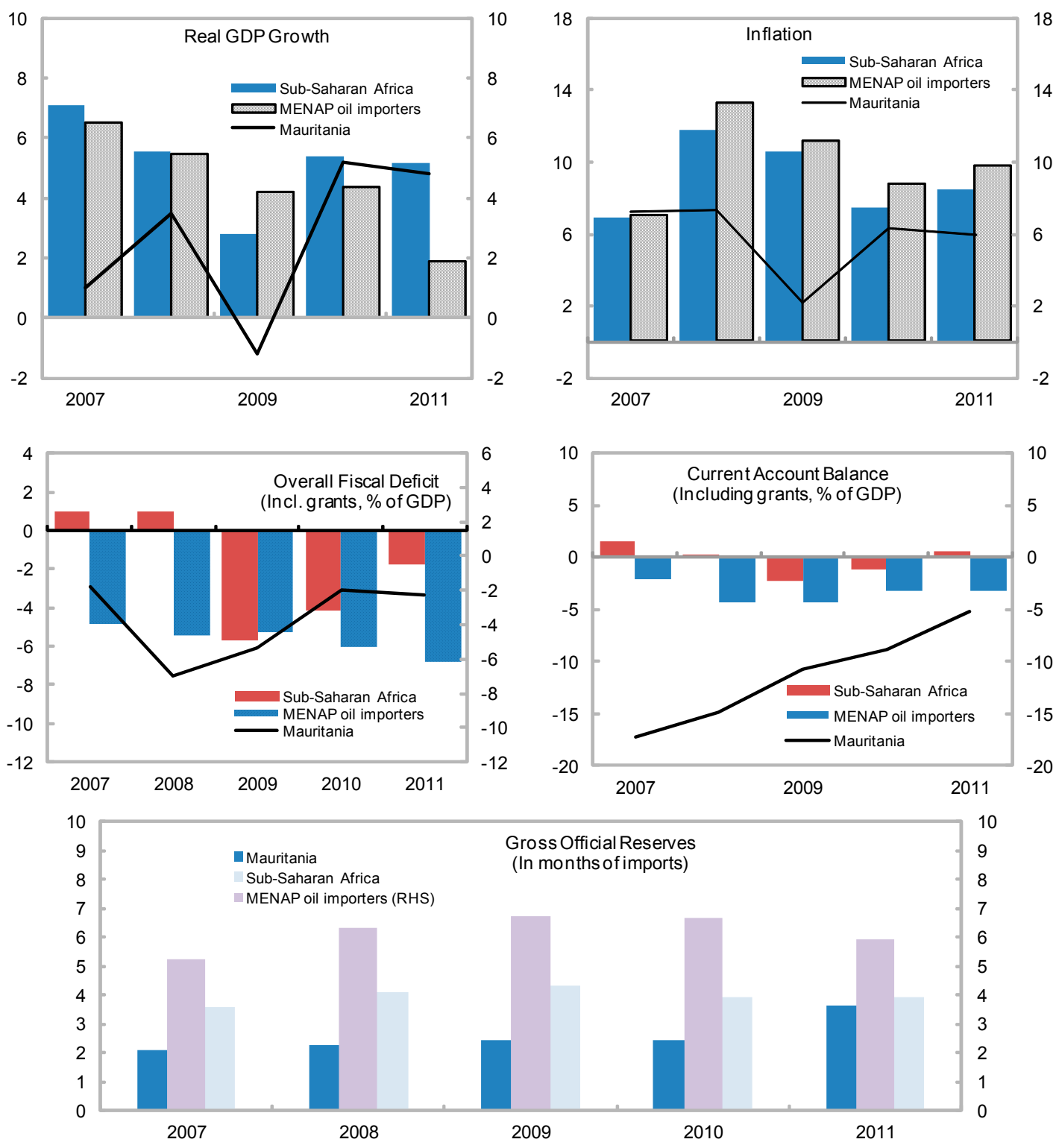

Sources: Mauritanian authorities; and Fund staff estimates; 
Figure 2. Mauritania: Real Sector Developments, 2007-11
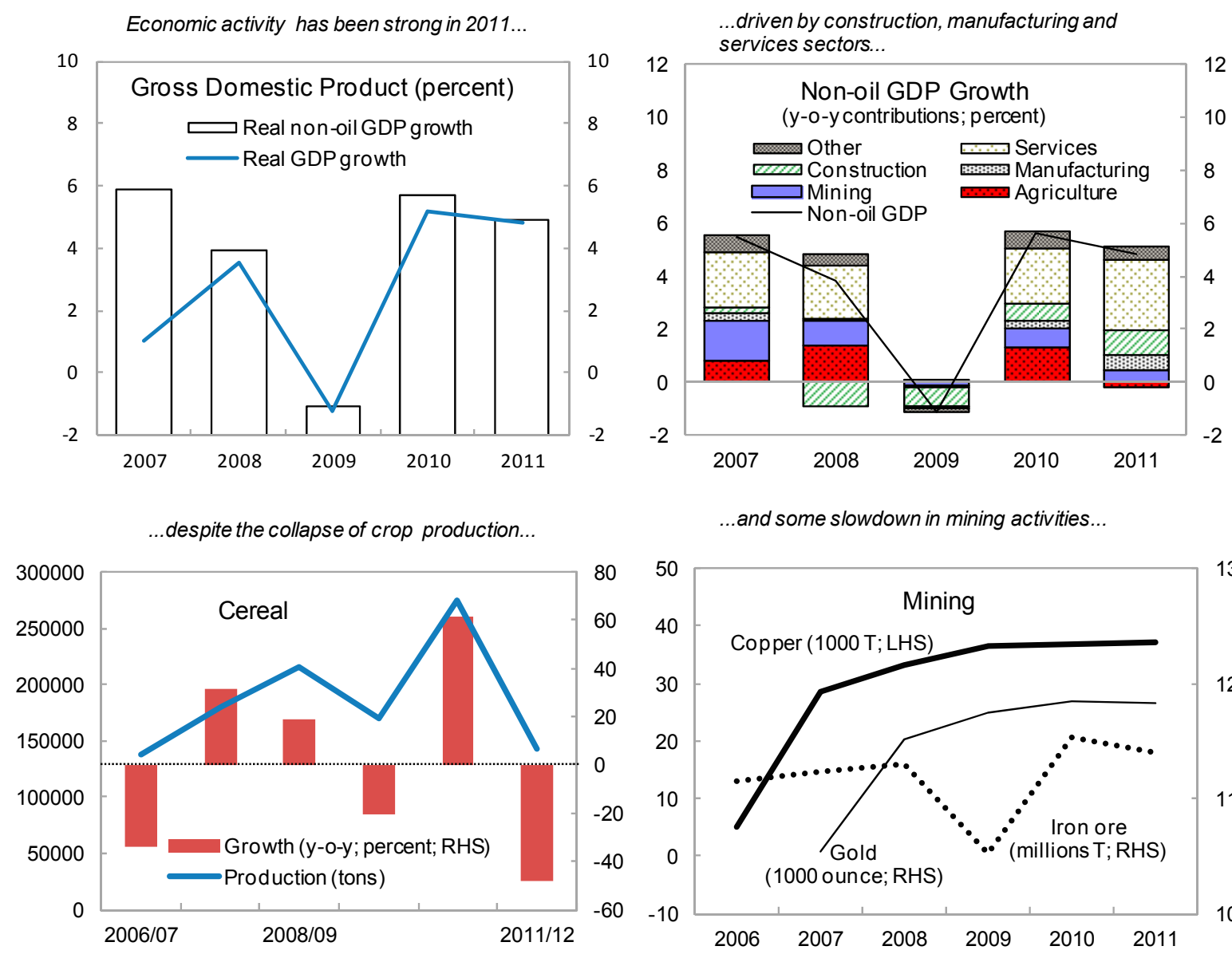

...and some slowdown in mining activities...
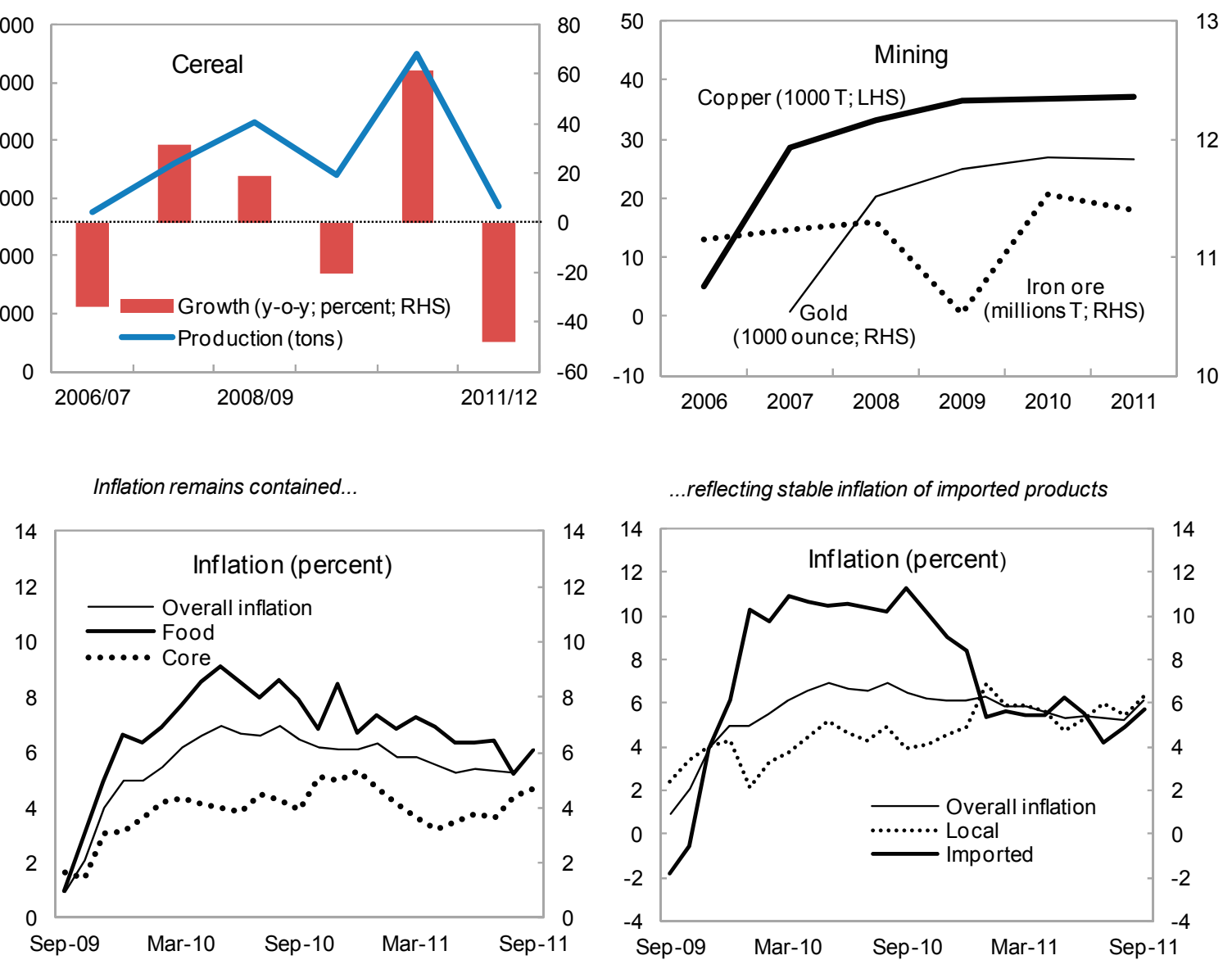

Sources: Mauritanian authorities; and Fund staff estimates. 
Figure 3. Mauritania: Selected Monetary and Financial Sector Indicators, 2007-11

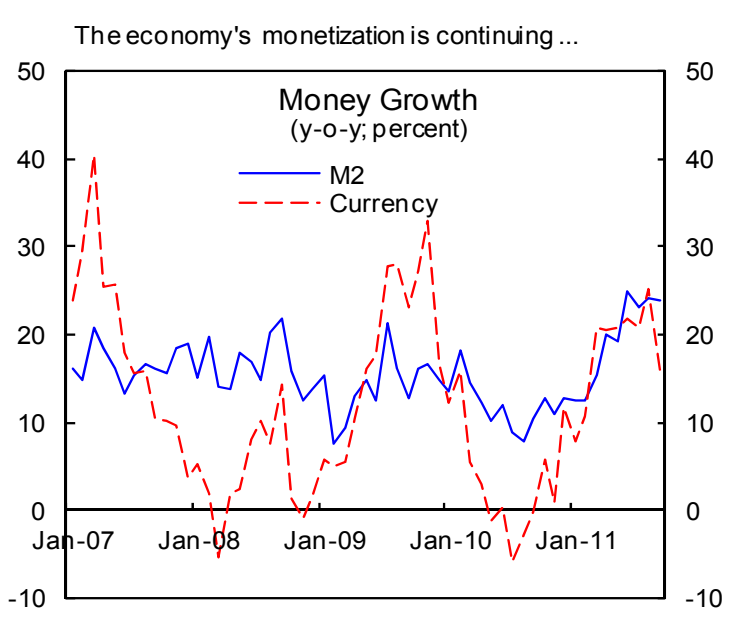

... without fuelling a cred it boom given structural weaknesses in the banking sector.

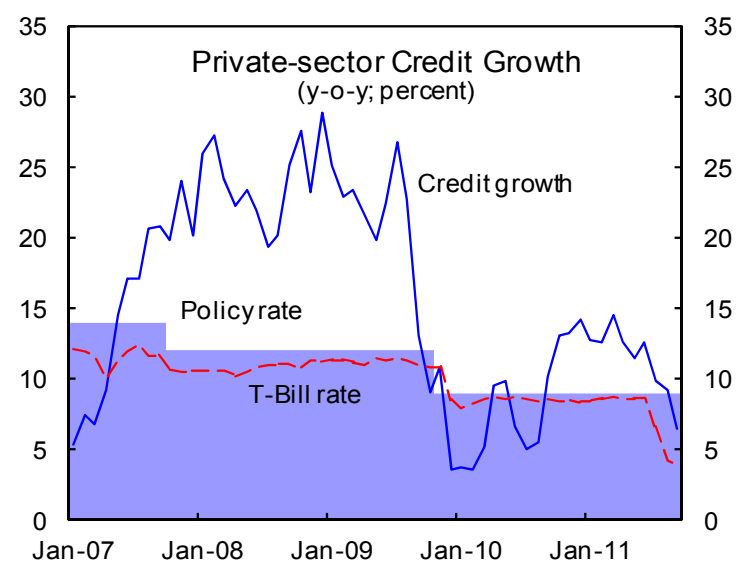

Government borrowing remains an important source of credit demand...

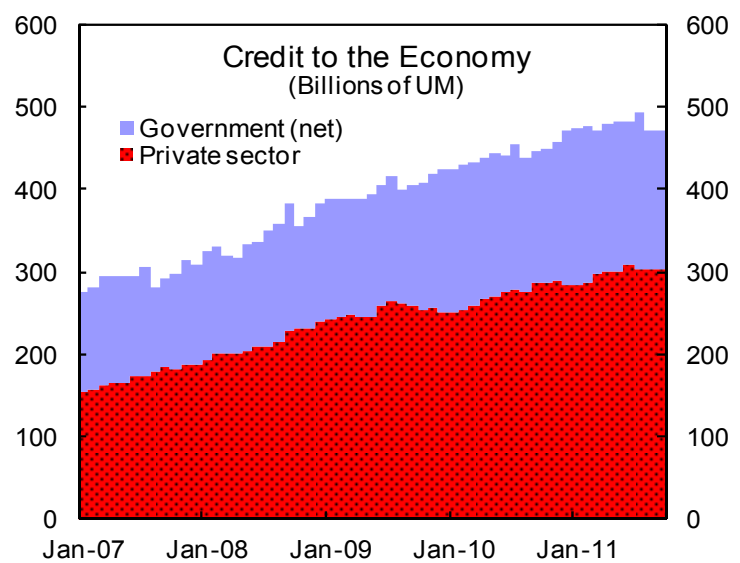

... while private-sector bo rrowing is increasingly driven by households.

Private-sector Credit by Industry (August 2011)

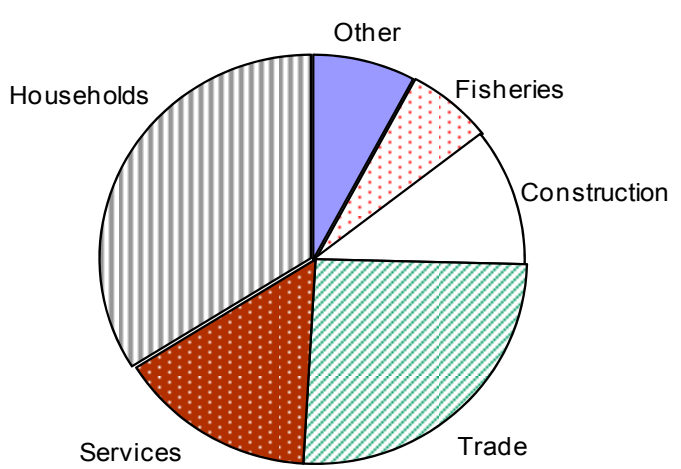

Banks are relatively well cap italized, but profitability has been low...

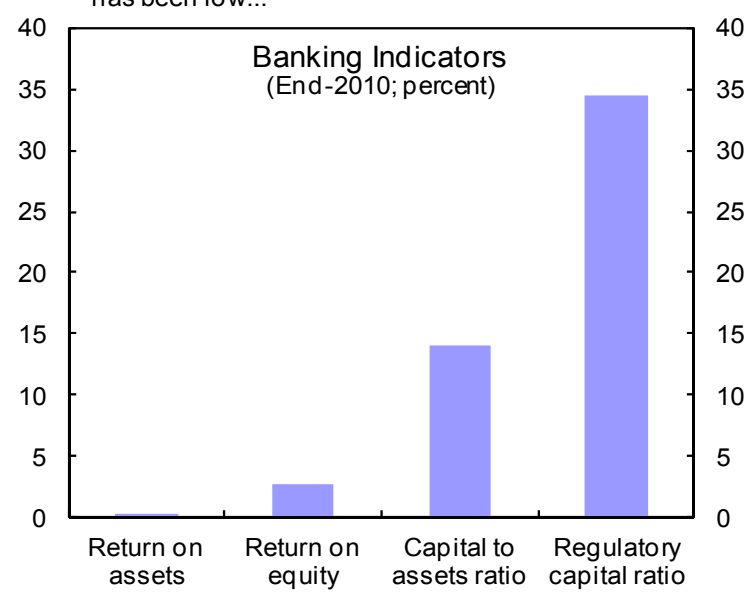

... due to high provisioning needs for nonperforming loans.

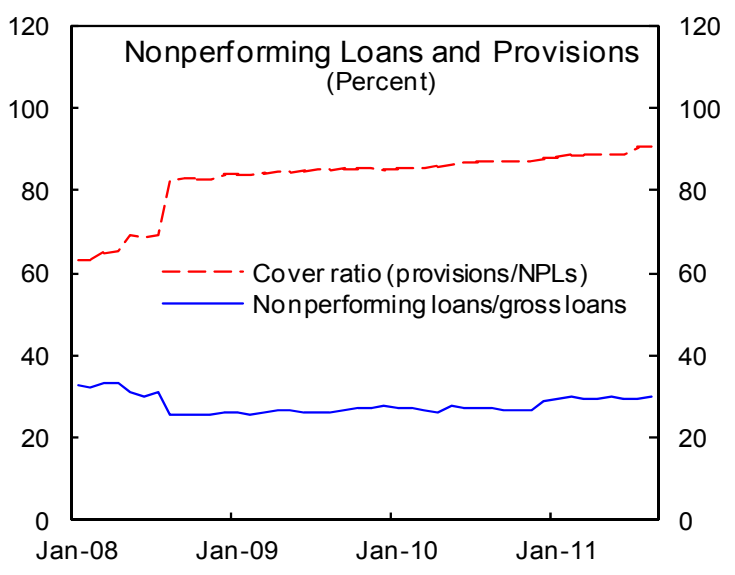

Sources: Mauritanian authorities; and Fund staff estimates. 
Figure 4. Mauritania: External Sector, 2007-11

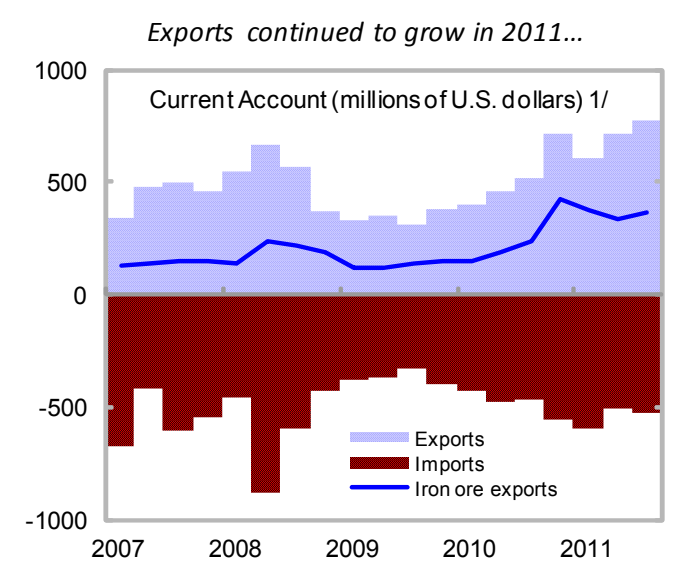

Exchange rate depreciated somewhat in 2011 while premium in the parallel market

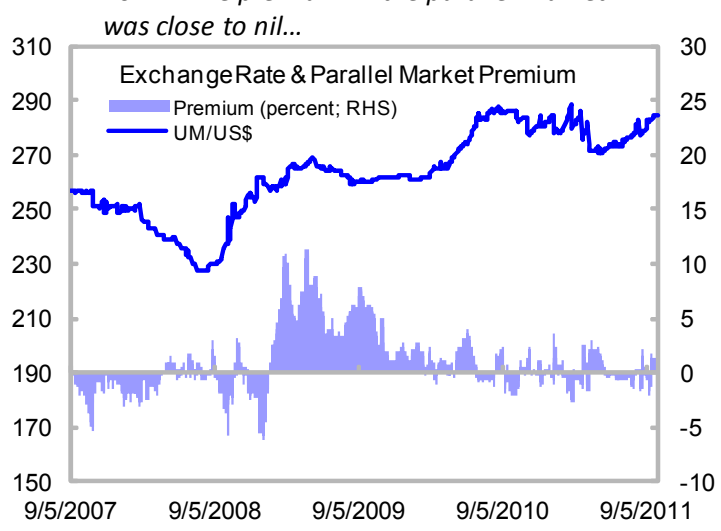

SNIM and TASIAST mining revenue remains an essential source of foreign exchange inflows...

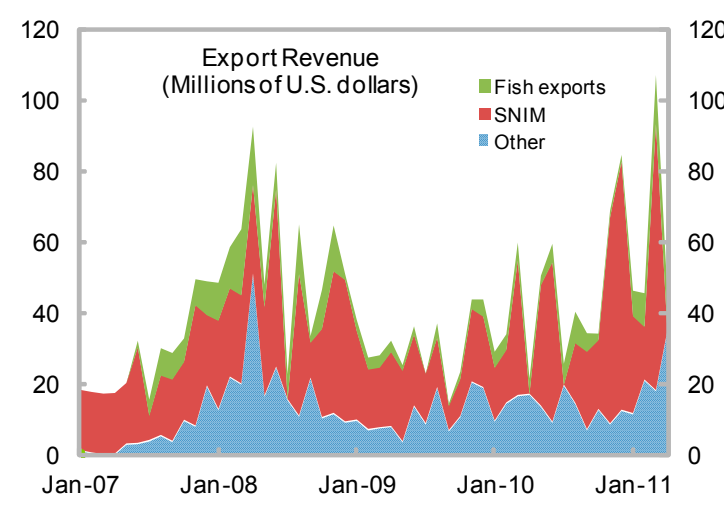

Sources: Mauritanian authorities; and Fund staff estimates.

1/ Updated to third quarter of 2011

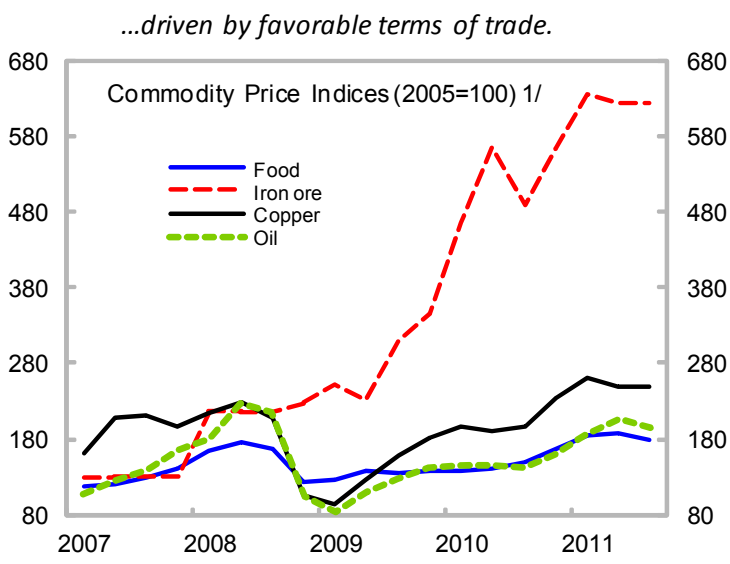

...helped by smaller and less frequent interventions by the central bank.

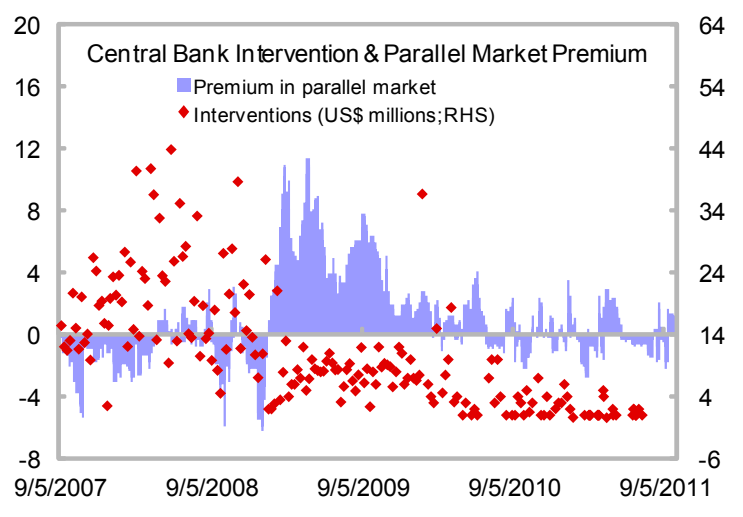

... helping boost gross international reserves.

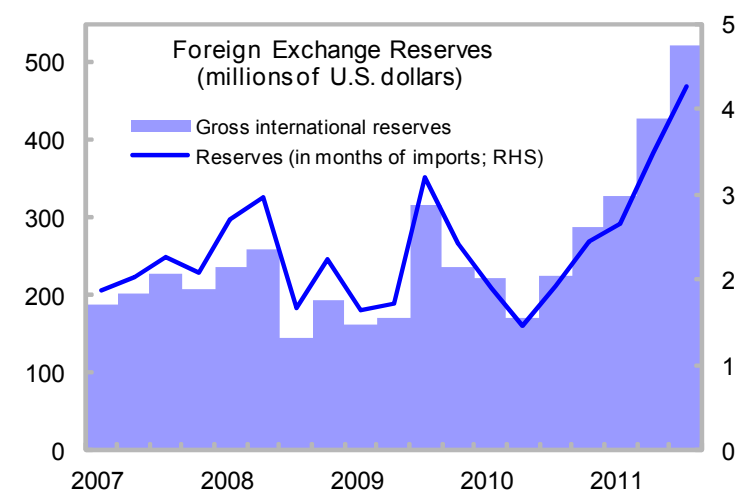


Figure 5. Mauritania: Fiscal Developments, 2007-11

(Percent of non-oil GDP, unless otherwise indicated)

Fiscal balances have improved..

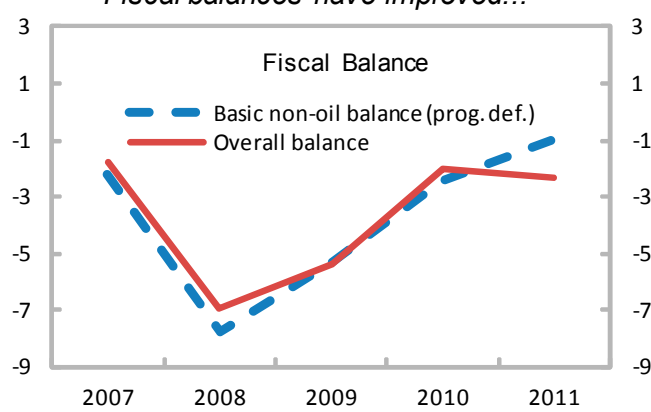

....and restrained spending...

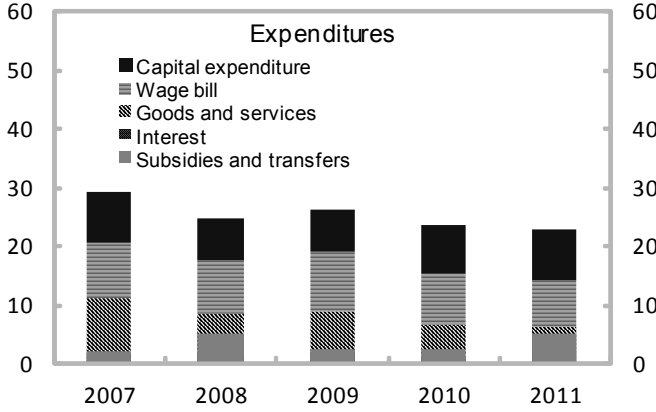

Poverty-related spending increased...

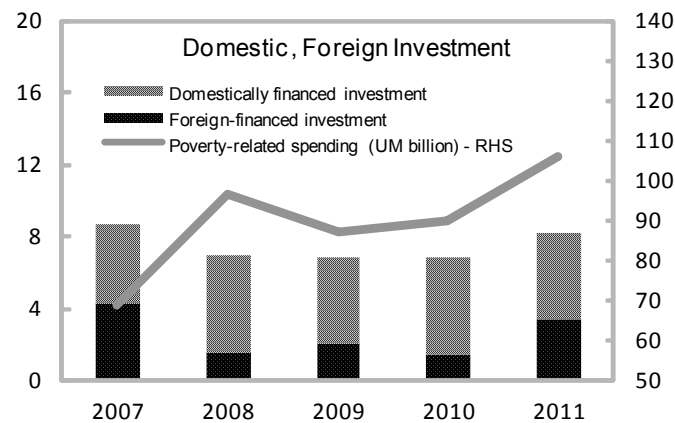

Sources: Mauritanian authorities; and Fund staff estimates. ...because of higher non-oil revenues...

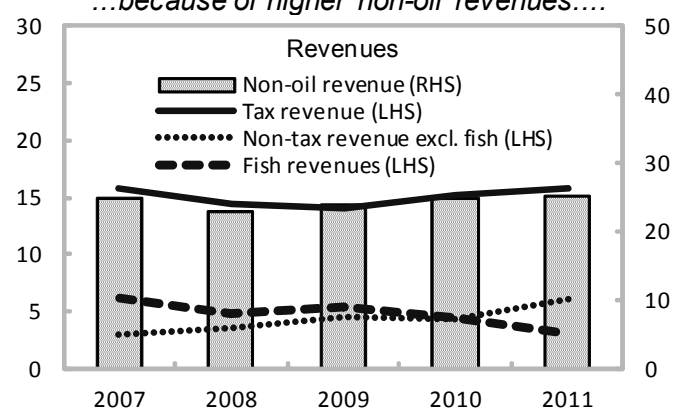

...leading to lower financing needs.

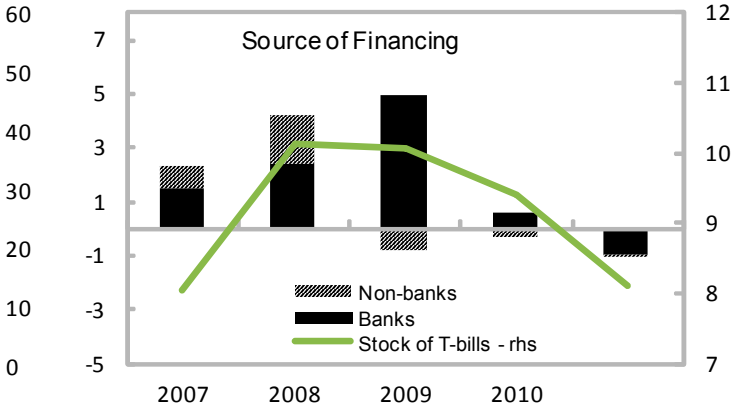

...thanks to increased capital spending and donorassistance.

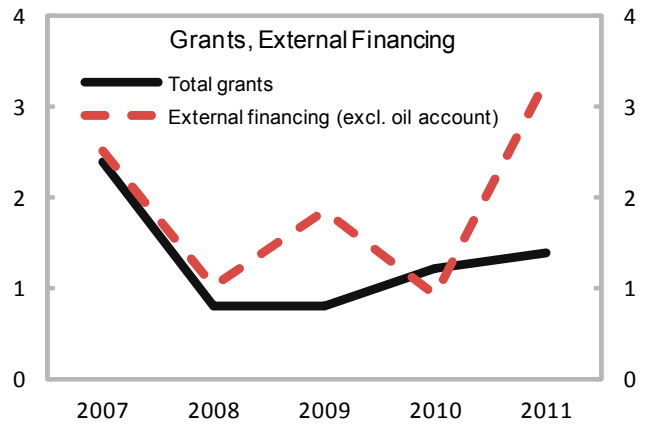


Table 1. Mauritania: Selected Economic and Financial Indicators, 2008-12

(Quota: SDR 64.4 million)

(Population: 3.22 million; 2009)

(Per capita GDP: $\$ 1,151 ; 2010)$

(Poverty rate: 42 percent; 2008 )

(Main exports: Iron ore, gold, fish; 2010)

\begin{tabular}{|c|c|c|c|c|c|c|c|}
\hline & 2008 & 2009 & $\begin{array}{l}2010 \\
\text { Est. }\end{array}$ & $\begin{array}{r}2011 \\
C R / 11 / 189\end{array}$ & $\begin{array}{l}2011 \\
\text { Proj. }\end{array}$ & $\begin{array}{r}2012 \\
C R / 11 / 189\end{array}$ & $\begin{array}{l}2012 \\
\text { Proj. }\end{array}$ \\
\hline & \multicolumn{7}{|c|}{ (Percent; unless otherwise indicated) } \\
\hline \multicolumn{8}{|l|}{ National income and prices (y-o-y growth) } \\
\hline GDP at constant prices & 3.5 & -1.2 & 5.2 & 5.1 & 4.8 & 5.7 & 5.5 \\
\hline Non-oil GDP at constant prices & 3.9 & -1.1 & 5.7 & 5.3 & 4.9 & 5.8 & 5.6 \\
\hline GDP excl. extractive industries at constant prices & 3.4 & -1.1 & 5.7 & 5.2 & 5.1 & 5.3 & 5.0 \\
\hline Oil production (1000 barrels per day) & 12.1 & 10.7 & 8.3 & 7.5 & 8.0 & 7.5 & 8.0 \\
\hline GDP deflator & 12.4 & -5.9 & 19.3 & 9.4 & 13.9 & 5.9 & 5.5 \\
\hline Non-oil GDP deflator & 13.0 & -3.9 & 19.0 & 9.2 & 13.5 & 6.2 & 6.1 \\
\hline GDP excl. extractive industries deflator & 7.1 & 1.0 & 6.6 & 5.9 & 4.1 & 5.5 & 4.2 \\
\hline Consumer price index (period average) & 7.3 & 2.2 & 6.3 & 7.3 & 5.9 & 6.7 & 6.8 \\
\hline Consumer price index (end of period) & 3.9 & 5.0 & 6.1 & 7.5 & 6.7 & 6.6 & 6.8 \\
\hline \multicolumn{8}{|l|}{ External sector } \\
\hline Value growth of exports of goods, f.o.b. & 27.5 & -23.7 & 52.0 & 37.5 & 38.2 & 7.4 & 6.2 \\
\hline Value growth of imports of goods, f.o.b. & 21.8 & -27.2 & 39.1 & 27.5 & 20.2 & 10.7 & 7.8 \\
\hline Current account balance (in percent of GDP) & -14.8 & -10.7 & -8.8 & -7.5 & -5.3 & -9.2 & -7.2 \\
\hline \multicolumn{8}{|l|}{ Gross official reserves $1 /$} \\
\hline In millions of U.S. dollars, end of period & 194.9 & 238.5 & 287.8 & 395.1 & 445.2 & 441.3 & 513.8 \\
\hline In months of following year's imports excluding extractive indust & 2.2 & 2.4 & 2.5 & 2.7 & 3.6 & 3.0 & 4.2 \\
\hline PPG external debt (percent of GDP) & 80.8 & 91.9 & 76.8 & 54.8 & 50.7 & 55.8 & 51.9 \\
\hline \multicolumn{8}{|l|}{ Money } \\
\hline Money and quasi-money (percentage change) & 13.7 & 14.9 & 12.9 & 13.3 & 19.4 & 13.3 & 13.2 \\
\hline Credit to the private sector (percentage change) & 28.9 & 3.7 & 14.2 & 12.8 & 11.3 & 11.7 & 12.4 \\
\hline \multicolumn{8}{|l|}{ Investment and savings } \\
\hline Gross investment (percentage of GDP) & 27.3 & 24.6 & 24.5 & 25.7 & 29.7 & 27.3 & 33.2 \\
\hline Gross savings (percentage of GDP) & 12.5 & 13.9 & 15.7 & 18.2 & 24.5 & 18.1 & 26.0 \\
\hline Consolidated government operations & \multicolumn{7}{|c|}{ (Percent of non-oil GDP; unless otherwise indicated) } \\
\hline Revenue and grants & 25.9 & 26.7 & 27.7 & 27.4 & 27.8 & 25.8 & 26.8 \\
\hline Non-oil revenue & 22.9 & 24.1 & 25.1 & 24.9 & 25.1 & 23.7 & 24.4 \\
\hline Oil revenue & 2.2 & 1.8 & 1.4 & 1.2 & 1.3 & 1.1 & 1.2 \\
\hline Expenditure and net lending & 32.9 & 32.1 & 29.7 & 30.3 & 30.1 & 29.9 & 30.2 \\
\hline Basic non-oil balance; program definition 2/ & -7.7 & -5.3 & -2.4 & -1.6 & -1.0 & -0.8 & -0.7 \\
\hline Overall balance including grants & -7.0 & -5.4 & -2.0 & -2.8 & -2.3 & -4.1 & -3.4 \\
\hline Public sector debt (percent of GDP) & 90.6 & 101.5 & 86.2 & 63.1 & 58.4 & 63.7 & 59.5 \\
\hline \multicolumn{8}{|l|}{ Memorandum items: } \\
\hline Nominal GDP (in billions of UM) & 854.0 & 794.2 & 997.0 & 1147.0 & 1190.0 & 1284.0 & 1324.1 \\
\hline Nominal non-oil GDP (in billions of UM) & 796.8 & 757.6 & 952.8 & 1096.0 & 1134.4 & 1232.0 & 1271.0 \\
\hline Nominal GDP (in millions of U.S. dollars) & 3536.3 & 3031.2 & 3628.6 & 3999.0 & 4227.1 & 4322.0 & 4538.3 \\
\hline Price of iron ore (US $\$ / T o n)$ & 61.6 & 80.0 & 146.7 & 182.8 & 176.9 & 172.5 & 169.5 \\
\hline
\end{tabular}

Sources: Mauritanian authorities; and Fund staff estimates and projections.

1/ Excluding the oil account.

2/ Defined as government non-oil revenue (excluding grants) minus government expenditure (excluding foreign-financed investment expenditure and interest on external debt). 
Table 2. Mauritania: Balance of Payments, 2008-12

(In millions of U.S. dollars, unless otherwise indicated)

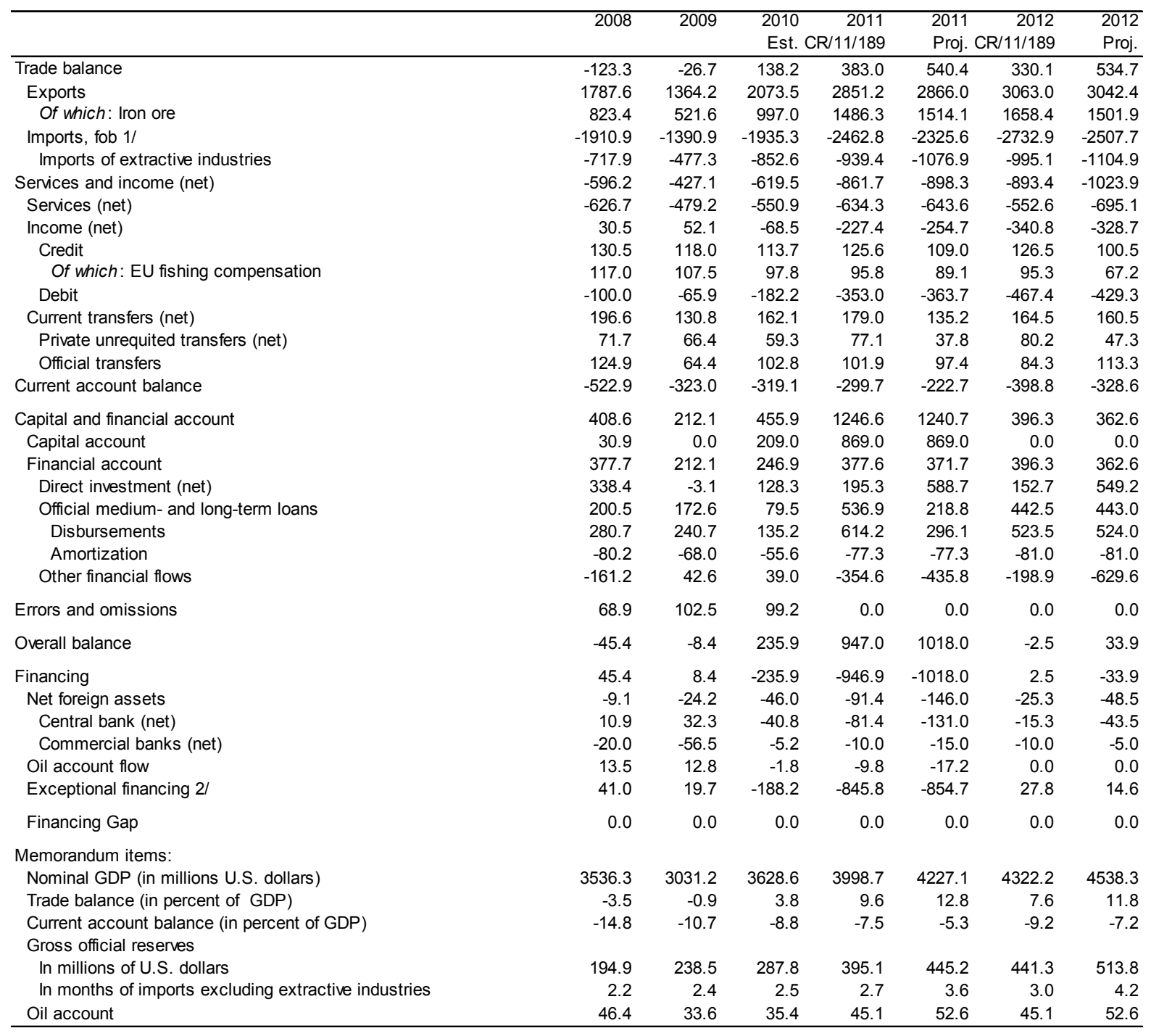

Sources: Mauritanian authorities; and Fund staff estimates and projections.

1/ Total imports in 2012 are lower than programmed in CR/11/189 due to a downward revision of other imports such as garments, cars, and construction materials.

2/ MDRI debt and assumed arrears relief (including passive debt owed to Kuwait and Libya) is treated as a one-time stock operation. 
Table 3. Mauritania: External Financing Requirements, 2009-13

(In millions of U.S. dollars)

\begin{tabular}{|c|c|c|c|c|c|}
\hline & 2009 & $\begin{array}{c}2010 \\
\text { Est. }\end{array}$ & $\begin{array}{l}2011 \\
\text { Proj. }\end{array}$ & $\begin{array}{l}2012 \\
\text { Proj. }\end{array}$ & $\begin{array}{l}2013 \\
\text { Proj. }\end{array}$ \\
\hline Total Requirements & -372 & -355 & -287 & -397 & -474 \\
\hline Current account deficit & -323 & -319 & -223 & -329 & -411 \\
\hline Scheduled public debt amortization & -49 & -36 & -64 & -68 & -64 \\
\hline Total Sources & 372 & 355 & 287 & 397 & 474 \\
\hline Capital inflows & 361 & 346 & 345 & 416 & 495 \\
\hline FDI, net & -3 & 128 & 589 & 549 & 599 \\
\hline Disbursements from official creditors (WB, AfDB, FADES) & 193 & 131 & 129 & 254 & 256 \\
\hline Other flows $1 /$ & 172 & 87 & -373 & -388 & -360 \\
\hline Of which: SNIM disbursements & 27 & 0 & 100 & 270 & 250 \\
\hline Financing Items & 41 & 60 & 116 & 50 & 32 \\
\hline IMF & 0 & 35 & 35 & 35 & 18 \\
\hline France & 0 & 4 & 46 & 0 & 0 \\
\hline Arab Monetary Fund & 22 & 0 & 22 & 0 & 0 \\
\hline Exceptional financing 1/ & 20 & 21 & 14 & 15 & 14 \\
\hline Change in oil account (- increase) & 13 & -2 & -17 & 0 & -17 \\
\hline Change in reserves (- increase) & -44 & -49 & -157 & -69 & -37 \\
\hline Residual financing gap & 0 & 0 & 0 & 0 & 0 \\
\hline \multicolumn{6}{|l|}{ Memorandum item: } \\
\hline Overall balance 1/ & -8 & 27 & 149 & 34 & 45 \\
\hline
\end{tabular}

Source: Mauritanian authorities, and Fund staff estimates and projections.

1/ Arrears to Kuwait are not included. 
Table 4a. Mauritania: Central Government Operations, 2008-12

(In billions of ouguiyas, unless otherwise indicated)

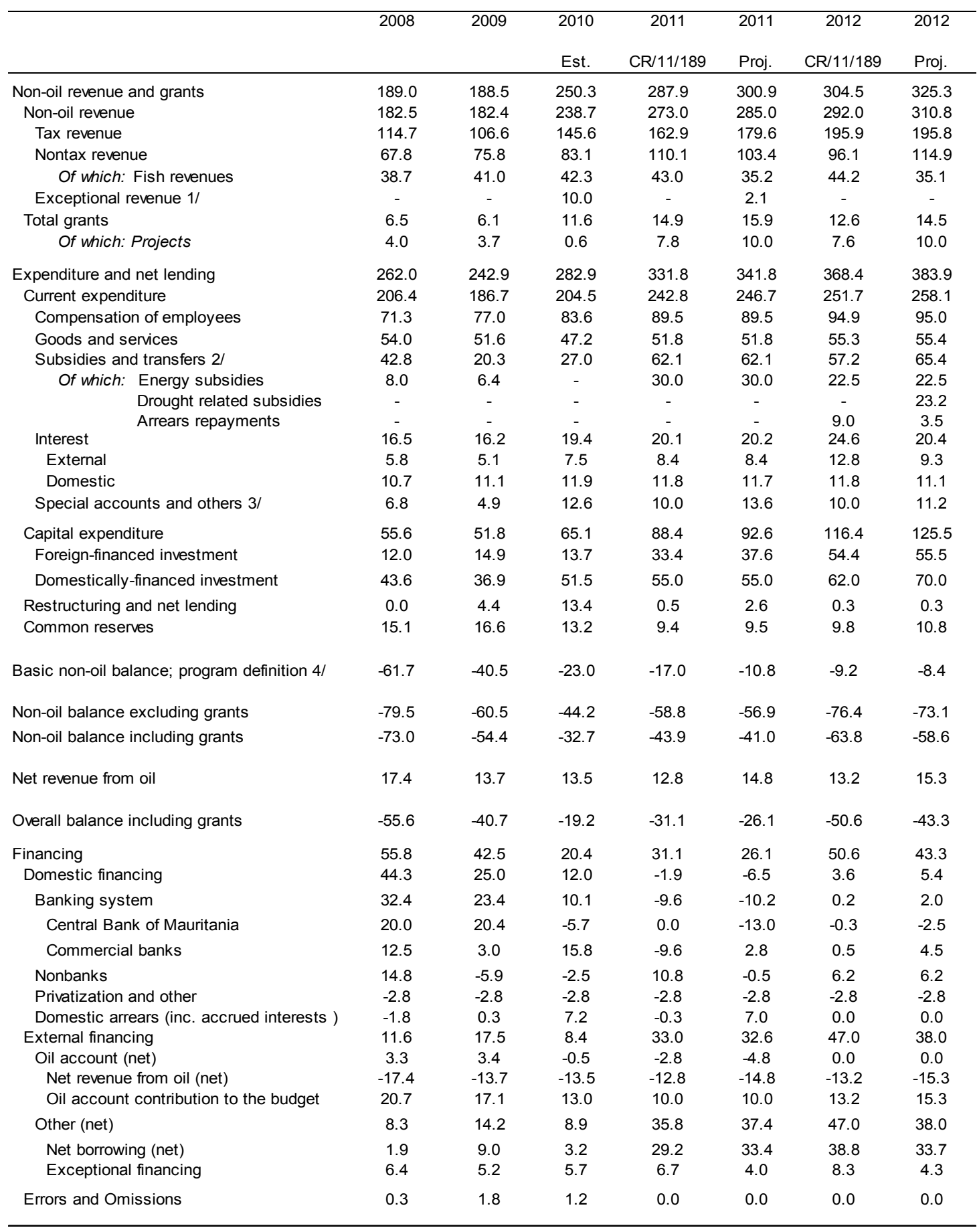

Sources: Mauritanian authorities; and Fund staff estimates and projections.

1/ Tax arrears from the public electricity company.

2/ Including transfers to public entities outside the central government. For 2012, it also includes payments arrears to hydrocarbon companies and SOMELEC.

3/ These include the development fund (FAID).

4/ Defined as government non-oil revenue (excluding grants) minus government expenditure (excluding foreign-financed investment expenditure and interest on external debt). 
Table 4b. Mauritania: Central Government Operations, 2008-12

(In percent of non-oil GDP, unless otherwise indicated)

\begin{tabular}{|c|c|c|c|c|c|c|c|}
\hline & 2008 & 2009 & $\begin{array}{l}2010 \\
\text { Est. }\end{array}$ & $\begin{array}{c}2011 \\
\text { CR/11/189 }\end{array}$ & $\begin{array}{l}2011 \\
\text { Proj. }\end{array}$ & $\begin{array}{c}2012 \\
\mathrm{CR} / 11 / 189\end{array}$ & $\begin{array}{l}2012 \\
\text { Proj. }\end{array}$ \\
\hline Non-oil revenue and grants & 23.7 & 24.9 & 26.3 & 26.3 & 26.5 & 24.7 & 25.6 \\
\hline Non-oil revenue & 22.9 & 24.1 & 25.1 & 24.9 & 25.1 & 23.7 & 24.4 \\
\hline Tax revenue & 14.4 & 14.1 & 15.3 & 14.9 & 15.8 & 15.9 & 15.4 \\
\hline Nontax revenue & 8.5 & 10.0 & 8.7 & 10.0 & 9.1 & 7.8 & 9.0 \\
\hline Of which: Fish revenues & 4.9 & 5.4 & 4.4 & 3.9 & 3.1 & 3.6 & 2.8 \\
\hline Exceptional revenue 1/ & - & - & 1.0 & - & 0.2 & - & - \\
\hline Total grants & 0.8 & 0.8 & 1.2 & 1.4 & 1.4 & 1.0 & 1.1 \\
\hline Of which: Projects & 0.5 & 0.5 & 0.1 & 0.7 & 0.9 & 0.6 & 0.8 \\
\hline Expenditure and net lending & 32.9 & 32.1 & 29.7 & 30.3 & 30.1 & 29.9 & 30.2 \\
\hline Current expenditure & 25.9 & 24.6 & 21.5 & 22.2 & 21.7 & 20.4 & 20.3 \\
\hline Compensation of employees & 8.9 & 10.2 & 8.8 & 8.2 & 7.9 & 7.7 & 7.5 \\
\hline Goods and services & 6.8 & 6.8 & 5.0 & 4.7 & 4.6 & 4.5 & 4.4 \\
\hline Subsidies and transfers $2 /$ & 5.4 & 2.7 & 2.8 & 5.7 & 5.5 & 4.6 & 5.1 \\
\hline Of which: Energy subsidies & 1.0 & 0.8 & - & 2.7 & 2.6 & 1.8 & 1.8 \\
\hline Drought related subsidies & - & - & - & - & - & - & 1.8 \\
\hline Arrears repayments & - & - & - & - & - & 0.7 & 0.3 \\
\hline Interest & 2.1 & 2.1 & 2.0 & 1.8 & 1.8 & 2.0 & 1.6 \\
\hline External & 0.7 & 0.7 & 0.8 & 0.8 & 0.7 & 1.0 & 0.7 \\
\hline Domestic & 1.3 & 1.5 & 1.3 & 1.1 & 1.0 & 1.0 & 0.9 \\
\hline Special accounts and others $3 /$ & 0.9 & 0.7 & 1.3 & 0.9 & 1.2 & 0.8 & 0.9 \\
\hline Capital expenditure & 7.0 & 6.8 & 6.8 & 8.1 & 8.2 & 9.4 & 9.9 \\
\hline Foreign-financed investment & 1.5 & 2.0 & 1.4 & 3.1 & 3.3 & 4.4 & 4.4 \\
\hline Domestically-financed investment & 5.5 & 4.9 & 5.4 & 5.0 & 4.8 & 5.0 & 5.5 \\
\hline Restructuring and net lending & 0.0 & 0.6 & 1.4 & 0.0 & 0.2 & 0.0 & 0.0 \\
\hline Common reserves & 1.9 & 2.2 & 1.4 & 0.9 & 0.8 & 0.8 & 0.8 \\
\hline Basic non-oil balance; program definition 4/ & -7.7 & -5.3 & -2.4 & -1.6 & -1.0 & -0.8 & -0.7 \\
\hline Non-oil balance excluding grants & -10.0 & -8.0 & -4.6 & -5.4 & -5.0 & -6.2 & -5.8 \\
\hline Non-oil balance including grants & -9.2 & -7.2 & -3.4 & -4.0 & -3.6 & -5.2 & -4.6 \\
\hline Net revenue from oil & 2.2 & 1.8 & 1.4 & 1.2 & 1.3 & 1.1 & 1.2 \\
\hline Overall balance including grants & -7.0 & -5.4 & -2.0 & -2.8 & -2.3 & -4.1 & -3.4 \\
\hline Financing & 7.0 & 5.6 & 2.1 & 2.8 & 2.3 & 4.1 & 3.4 \\
\hline Domestic financing & 5.6 & 3.3 & 1.3 & -0.2 & -0.6 & 0.3 & 0.4 \\
\hline Banking system & 4.1 & 3.1 & 1.1 & -0.9 & -0.9 & 0.0 & 0.2 \\
\hline Central Bank of Mauritania & 2.5 & 2.7 & -0.6 & 0.0 & -1.1 & 0.0 & -0.2 \\
\hline Commercial banks & 1.6 & 0.4 & 1.7 & -0.9 & 0.2 & 0.0 & 0.4 \\
\hline Nonbanks & 1.9 & -0.8 & -0.3 & 1.0 & 0.0 & 0.5 & 0.5 \\
\hline Privatization and other & -0.4 & -0.4 & -0.3 & -0.3 & -0.2 & -0.2 & -0.2 \\
\hline Domestic arrears (inc. accrued interests ) & -0.2 & 0.0 & 0.8 & 0.0 & 0.6 & 0.0 & 0.0 \\
\hline External financing & 1.4 & 2.3 & 0.9 & 3.0 & 2.9 & 3.8 & 3.0 \\
\hline Oil account (net) & 0.4 & 0.4 & -0.1 & -0.3 & -0.4 & 0.0 & 0.0 \\
\hline Net revenue from oil (net) & -2.2 & -1.8 & -1.4 & -1.2 & -1.3 & -1.1 & -1.2 \\
\hline Oil account contribution to the budget & 2.6 & 2.3 & 1.4 & 0.9 & 0.9 & 1.1 & 1.2 \\
\hline Other (net) & 1.0 & 1.9 & 0.9 & 3.3 & 3.3 & 3.8 & 3.0 \\
\hline Net borrowing (net) & 0.2 & 1.2 & 0.3 & 2.7 & 2.9 & 3.1 & 2.7 \\
\hline Exceptional financing & 0.8 & 0.7 & 0.6 & 0.6 & 0.4 & 0.7 & 0.3 \\
\hline Errors and Omissions & 0.0 & 0.2 & 0.1 & 0.0 & 0.0 & 0.0 & 0.0 \\
\hline \multicolumn{8}{|l|}{ Memorandum items: } \\
\hline Non-oil GDP (in billions of ouguiya) & 796.8 & 757.6 & 952.8 & 1095.8 & 1134.4 & 1231.8 & 1271.0 \\
\hline Total revenue & 25.1 & 25.9 & 26.5 & 26.1 & 26.4 & 24.8 & 25.7 \\
\hline Tax Revenue excluding extractive industries & 15.9 & 15.3 & 17.2 & 17.5 & 18.8 & 17.9 & 18.8 \\
\hline Oil fund balance (in billions of ouguiya) & 11.7 & 8.8 & 9.7 & 12.9 & 14.8 & 13.4 & 15.3 \\
\hline
\end{tabular}

Sources: Mauritanian authorities; and Fund staff estimates and projections.

1/ Tax arrears from the public electricity company.

$2 /$ Including transfers to public entities outside the central government. For 2012, it also includes payments arrears

to hydrocarbon companies and SOMELEC.

3/ These include the development fund (FAID)

4/ Defined as government non-oil revenue (excluding grants) minus government expenditure (excluding foreign-financed investment expenditure and interest on external debt). 
Table 5. Mauritania: Monetary Situation, 2008-12

(In billions of ouguiyas at end-of-period exchange rates, unless otherwise indicated)

\begin{tabular}{|c|c|c|c|c|c|c|c|}
\hline & 2008 & 2009 & 2010 & 2011 & 2011 & 2012 & 2012 \\
\hline & & & Est. & $\mathrm{CR} / 11 / 189$ & Proj. & $\mathrm{CR} / 11 / 189$ & Proj. \\
\hline \multicolumn{8}{|l|}{ Monetary survey } \\
\hline Net foreign assets & -9.5 & -3.3 & 9.4 & 36.1 & 52.8 & 47.7 & 67.9 \\
\hline Net domestic assets & 250.1 & 279.9 & 302.7 & 317.6 & 317.1 & 353.9 & 350.2 \\
\hline Net domestic credit & 381.5 & 424.2 & 470.9 & 497.6 & 499.2 & 533.9 & 538.4 \\
\hline Net credit to the government & 141.7 & 175.5 & 186.8 & 177.2 & 183.1 & 175.8 & 183.0 \\
\hline Credit to the economy & 239.8 & 248.7 & 284.1 & 320.5 & 316.1 & 358.1 & 355.4 \\
\hline Other items net & -131.4 & -144.4 & -168.2 & -180.1 & -182.1 & -180.1 & -188.1 \\
\hline Broad money & 240.6 & 276.5 & 312.1 & 353.7 & 369.9 & 401.5 & 418.1 \\
\hline \multicolumn{8}{|l|}{ Monetary authorities } \\
\hline Net foreign assets & 10.1 & 1.6 & 13.3 & 37.2 & 51.6 & 45.8 & 65.1 \\
\hline Net domestic assets & 100.5 & 124.3 & 113.6 & 106.6 & 100.2 & 117.5 & 97.7 \\
\hline Net domestic credit & 115.3 & 146.2 & 141.1 & 141.1 & 134.6 & 139.3 & 132.1 \\
\hline Net credit to the government & 95.6 & 127.0 & 122.3 & 122.3 & 115.8 & 120.5 & 113.3 \\
\hline Other items net & -14.8 & -21.9 & -27.5 & -33.3 & -34.3 & -33.3 & -34.3 \\
\hline Reserve money & 110.6 & 125.9 & 126.9 & 143.8 & 151.8 & 163.2 & 162.9 \\
\hline Currency in circulation & 70.0 & 81.6 & 91.3 & 103.4 & 105.6 & 105.8 & 119.4 \\
\hline Reserves of banks & 40.6 & 44.3 & 35.6 & 40.3 & 46.2 & 57.4 & 43.5 \\
\hline Of which: Banks deposits in FX & 10.0 & 14.0 & 8.1 & 8.4 & 7.4 & 10.4 & 9.7 \\
\hline \multicolumn{8}{|l|}{ Commercial banks } \\
\hline Net foreign assets & -19.6 & -5.0 & -3.9 & -1.1 & 1.3 & 1.9 & 2.7 \\
\hline Net domestic credit & 269.6 & 280.7 & 334.0 & 360.8 & 368.9 & 398.8 & 410.5 \\
\hline Net credit to the government & 46.1 & 48.5 & 64.5 & 54.9 & 67.3 & 55.3 & 69.7 \\
\hline Credit to the private sector & 223.4 & 232.3 & 269.5 & 305.9 & 301.6 & 343.6 & 340.8 \\
\hline Other items net & -116.7 & -122.5 & -140.7 & -146.7 & -147.8 & -146.7 & -153.8 \\
\hline \multicolumn{8}{|l|}{ Memorandum items: } \\
\hline Velocity of broad money & 3.3 & 2.7 & 3.1 & 3.1 & 3.1 & 3.1 & 3.0 \\
\hline Velocity of broad money (GDP excluding, extractive industries) & 2.5 & 2.2 & 2.2 & 2.1 & 2.0 & 2.1 & 2.0 \\
\hline Credit to the private sector (percent of GDP) & 28.0 & 30.7 & 28.3 & 27.9 & 26.6 & 27.8 & 26.8 \\
\hline Net foreign assets of banks (in millions of U.S. dollars) & -74.8 & -18.9 & -13.8 & -3.8 & 4.3 & 6.2 & 9.3 \\
\hline
\end{tabular}

Sources: Mauritanian authorities; and Fund staff estimates and projections. 
Table 6. Mauritania: Banking System at a Glance, 2008-11

(Percent, unless otherwise indicated)

\begin{tabular}{|c|c|c|c|c|}
\hline & 2008 & 2009 & $\begin{array}{c}2010 \\
\text { Est. }\end{array}$ & $\begin{array}{l}2011 \\
\text { June }\end{array}$ \\
\hline \multicolumn{5}{|l|}{ Balance sheet } \\
\hline Assets (percent of non-oil GDP) & 45.2 & 52.5 & 46.6 & 47.5 \\
\hline Private-sector credit / total assets & 62.0 & 58.3 & 60.7 & 57.1 \\
\hline Public enterprise credit / total assets & 15.0 & 13.1 & 13.0 & - \\
\hline Government securities / total assets & 14.7 & 13.6 & 15.8 & 14.8 \\
\hline Private-sector credit growth (y-o-y) & 23.6 & 4.0 & 16.0 & 13.3 \\
\hline Nonperforming loans / gross loans & 26.4 & 27.7 & 28.7 & 29.7 \\
\hline Provisions / nonperforming loans & 84.1 & 85.2 & 87.7 & 88.7 \\
\hline Uncovered nonperforming loans / gross loans & 4.2 & 4.1 & 3.5 & 3.4 \\
\hline Deposits / total assets & 47.4 & 49.0 & 49.7 & 50.0 \\
\hline Private-sector loans / private-sector deposits & 130.9 & 119.2 & 122.1 & 114.3 \\
\hline \multicolumn{5}{|l|}{ Capital ratios } \\
\hline Capital / total assets & 14.2 & 14.2 & 14.0 & 16.7 \\
\hline Capital adequacy ratio & 33.0 & 37.9 & 34.5 & - \\
\hline \multicolumn{5}{|l|}{ Foreign exchange exposure } \\
\hline Fx assets / total assets & 5.1 & 8.4 & 7.0 & 6.7 \\
\hline Fx assets / fx liabilities (on balance sheet) & 75.0 & 123.7 & 112.1 & 126.7 \\
\hline \multicolumn{5}{|l|}{ Profitability and liquidity } \\
\hline Return on assets & 1.9 & 1.4 & 0.4 & - \\
\hline Return on equity & 10.7 & 8.5 & 2.7 & - \\
\hline Liquid assets / total assets $1 /$ & 26.4 & 25.4 & 24.8 & 24.6 \\
\hline \multicolumn{5}{|l|}{ Memorandum items: } \\
\hline Share of assets held by three largest banks & 53.4 & 53.6 & 53.7 & 52.3 \\
\hline Number of banks & 10.0 & 10.0 & 10.0 & 12.0 \\
\hline Private sector credit / GDP & 26.2 & 29.2 & 27.0 & - \\
\hline
\end{tabular}

Sources: Mauritanian authorities; and Fund staff.

1/ Liquid assets: cash, reserves, and treasury bills. 
Table 7. Mauritania: Indicators of Capacity to Repay the Fund, 2012-16

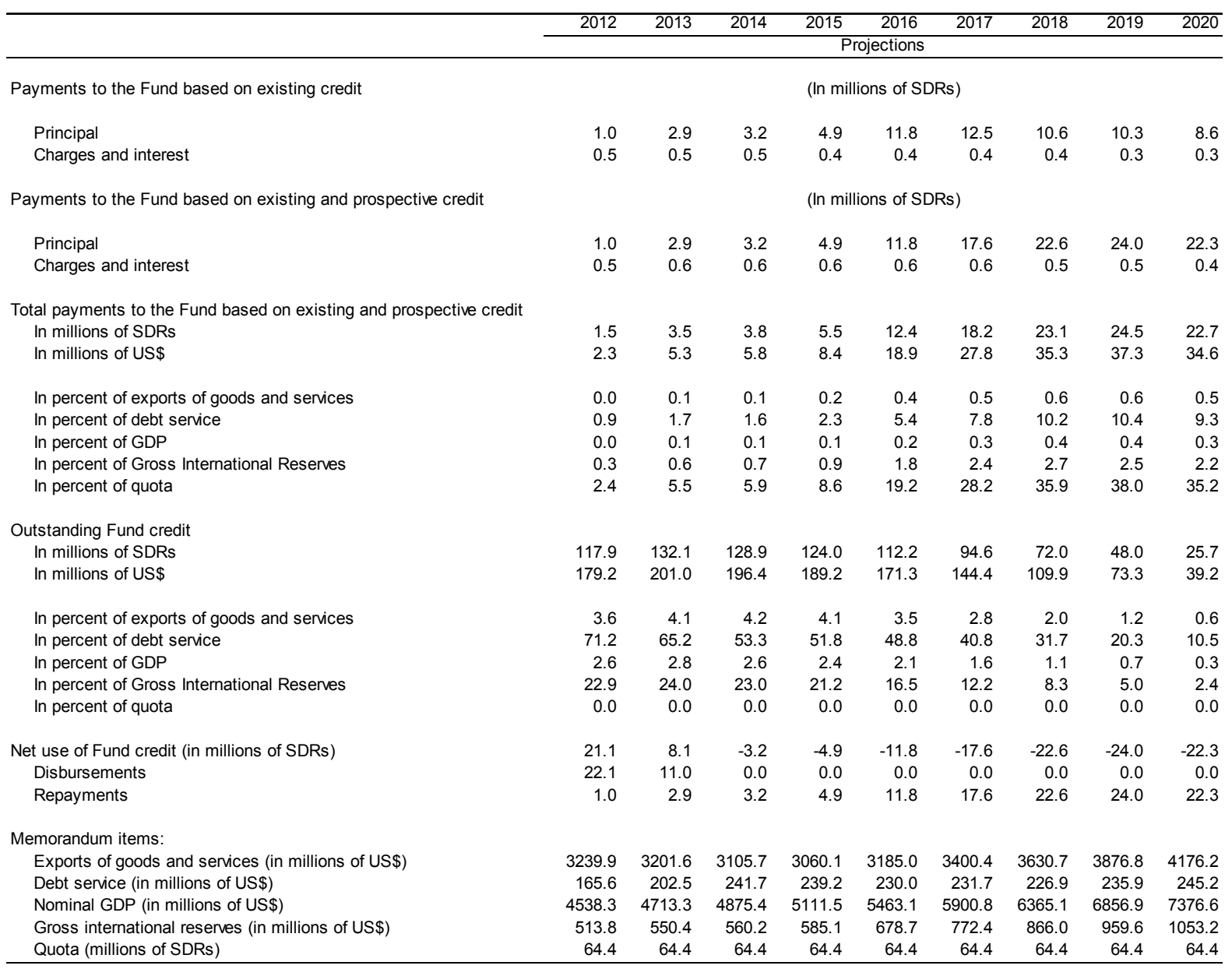

Sources: Fund staff estimates and projections. 
Table 8. Mauritania: Selected Economic and Financial Indicators, 2008-16

\begin{tabular}{|c|c|c|c|c|c|c|c|c|c|c|c|}
\hline & 2008 & 2009 & $\begin{array}{r}2010 \\
\text { Est. }\end{array}$ & $\begin{array}{r}2011 \\
\mathrm{CR} / 11 / 189 \\
\end{array}$ & $\begin{array}{l}2011 \\
\text { Proj. }\end{array}$ & $\begin{array}{r}2012 \\
C R / 11 / 189 \\
\end{array}$ & $\begin{array}{l}2012 \\
\text { Proj. }\end{array}$ & $\begin{array}{l}2013 \\
\text { Proj. }\end{array}$ & $\begin{array}{l}2014 \\
\text { Proj. }\end{array}$ & $\begin{array}{l}2015 \\
\text { Proj. }\end{array}$ & $\begin{array}{l}2016 \\
\text { Proj. }\end{array}$ \\
\hline & \multicolumn{11}{|c|}{ (Percent; unless otherwise indicated) } \\
\hline \multicolumn{12}{|l|}{ National income and prices (y-o-y growth) } \\
\hline GDP at constant prices & 3.5 & -1.2 & 5.2 & 5.1 & 4.8 & 5.7 & 5.5 & 6.2 & 5.6 & 5.5 & 5.5 \\
\hline Non-oil GDP at constant prices & 3.9 & -1.1 & 5.7 & 5.3 & 4.9 & 5.8 & 5.6 & 6.2 & 5.6 & 5.5 & 5.5 \\
\hline GDP excl. extractive industries at constant prices & 3.4 & -1.1 & 5.7 & 5.2 & 5.1 & 5.3 & 5.0 & 5.9 & 5.3 & 5.5 & 5.5 \\
\hline Oil production (1000 barrels per day) & 12.1 & 10.7 & 8.3 & 7.5 & 8.0 & 7.5 & 8.0 & 8.0 & 8.0 & 8.0 & 8.0 \\
\hline GDP deflator & 12.4 & -5.9 & 19.3 & 9.4 & 13.9 & 5.9 & 5.5 & 1.1 & 0.8 & 1.9 & 3.6 \\
\hline Non-oil GDP deflator & 13.0 & -3.9 & 19.0 & 9.2 & 13.5 & 6.2 & 6.1 & 1.4 & 1.1 & 2.2 & 3.8 \\
\hline GDP excl. extractive industries deflator & 7.1 & 1.0 & 6.6 & 5.9 & 4.1 & 5.5 & 4.2 & 5.0 & 5.1 & 5.1 & 5.0 \\
\hline Consumer price index (period average) & 7.3 & 2.2 & 6.3 & 7.3 & 5.9 & 6.7 & 6.8 & 6.5 & 6.1 & 5.7 & 5.3 \\
\hline Consumer price index (end of period) & 3.9 & 5.0 & 6.1 & 7.5 & 6.7 & 6.6 & 6.8 & 6.3 & 5.9 & 5.5 & 5.1 \\
\hline \multicolumn{12}{|l|}{ External sector } \\
\hline Value growth of exports of goods, f.o.b. & 27.5 & -23.7 & 52.0 & 37.5 & 38.2 & 7.4 & 6.2 & -1.4 & -3.4 & -1.8 & 4.1 \\
\hline Value growth of imports of goods, f.o.b. & 21.8 & -27.2 & 39.1 & 27.5 & 20.2 & 10.7 & 7.8 & 1.7 & 0.5 & -1.7 & 3.6 \\
\hline Current account balance (in percent of GDP) & -14.8 & -10.7 & -8.8 & -7.5 & -5.3 & -9.2 & -7.2 & -8.7 & -11.0 & -9.8 & -7.4 \\
\hline \multicolumn{12}{|l|}{ Gross official reserves $1 /$} \\
\hline In millions of U.S. dollars, end of period & 194.9 & 238.5 & 287.8 & 395.1 & 445.2 & 441.3 & 513.8 & 550.4 & 560.2 & 585.1 & 678.7 \\
\hline In months of following year's imports excluding extractive industries & 2.2 & 2.4 & 2.5 & 2.7 & 3.6 & 3.0 & 4.2 & 4.5 & 4.7 & 4.7 & 4.9 \\
\hline PPG external debt (percent of GDP) & 80.8 & 91.9 & 76.8 & 54.8 & 50.7 & 55.8 & 51.9 & 56.2 & 56.9 & 57.0 & 53.8 \\
\hline \multicolumn{12}{|l|}{ Money } \\
\hline Money and quasi-money (percentage change) & 13.7 & 14.9 & 12.9 & 13.3 & 19.4 & 13.3 & 13.2 & 14.1 & 13.2 & 13.7 & 13.7 \\
\hline Credit to the private sector (percentage change) & 28.9 & 3.7 & 14.2 & 12.8 & 11.3 & 11.7 & 12.4 & 12.8 & 12.3 & 12.1 & 12.1 \\
\hline \multicolumn{12}{|l|}{ Investment and savings } \\
\hline Gross investment (percentage of GDP) & 27.3 & 24.6 & 24.5 & 25.7 & 29.7 & 27.3 & 33.2 & 33.4 & 31.9 & 27.6 & 26.6 \\
\hline Gross savings (percentage of GDP) & 12.5 & 13.9 & 15.7 & 18.2 & 24.5 & 18.1 & 26.0 & 24.6 & 20.9 & 17.9 & 19.2 \\
\hline Consolidated government operations & \multicolumn{11}{|c|}{ (Percent of non-oil GDP; unless otherwise indicated) } \\
\hline Basic non-oil balance; program definition $2 /$ & -7.7 & -5.3 & -2.4 & -1.6 & -1.0 & -0.8 & -0.7 & -0.1 & 0.3 & 0.5 & 1.8 \\
\hline Overall balance including grants & -7.0 & -5.4 & -2.0 & -2.8 & -2.3 & -4.1 & -3.4 & -2.8 & -2.5 & -1.2 & 0.1 \\
\hline Public sector debt (percent of GDP) & 90.6 & 101.5 & 86.2 & 63.1 & 58.4 & 63.7 & 59.5 & 63.7 & 64.7 & 64.9 & 60.7 \\
\hline \multicolumn{12}{|l|}{ Memorandum items: } \\
\hline Nominal GDP (in billions of UM) & 854.0 & 794.2 & 997.0 & 1147.0 & 1190.0 & 1284.0 & 1324.1 & 1421.0 & 1512.2 & 1625.4 & 1775.1 \\
\hline GDP per capita (in U.S. dollars) & 1123.1 & 940.1 & 1099.0 & 3999.0 & 1250.2 & 4322.0 & 1310.8 & 1329.5 & 1343.0 & 1375.0 & 1435.1 \\
\hline Price of iron ore (US $\$ / T o n)$ & 61.6 & 80.0 & 146.7 & 182.8 & 176.9 & 172.5 & 169.5 & 147.0 & 127.0 & 122.0 & 122.0 \\
\hline
\end{tabular}

Sources: Mauritanian authorities; and Fund staff estimates and projections.

1/ Excluding the oil account.

2/ Defined as government non-oil revenue (excluding grants) minus government expenditure (excluding foreign-financed investment expenditure and interest on external debt). 
Table 9. Mauritania: Access and Phasing Under the Three-Year ECF Arrangement, 2010-13 1/

\begin{tabular}{|c|c|c|c|}
\hline \multirow[t]{2}{*}{ Timing } & \multicolumn{2}{|c|}{ Disbursement } & \multirow[t]{2}{*}{ Conditions } \\
\hline & Amount in SDR & Percent of Quota & \\
\hline March 15, 2010 & 11.04 & 17.14 & Approval of the arrangement. \\
\hline November 19, 2010 & 11.04 & 17.14 & Completion of the first review (relevant PCs for end-June 2010 ). \\
\hline June 22, 2011 & 11.04 & 17.14 & Completion of the second review (relevant PCs for end-December 2010). \\
\hline December 12, 2011 & 11.04 & 17.14 & Completion of the third review (relevant PCs for end-June 2011). \\
\hline June 1, 2012 & 11.04 & 17.14 & Completion of the fourth review (relevant PCs for end-December 2011). \\
\hline November 30, 2012 & 11.04 & 17.14 & Completion of the fifth review (relevant PCs for end-June 2012). \\
\hline June 30, 2013 & 11.04 & 17.14 & Completion of the sixth (final) review (relevant PCs for end-December 2012). \\
\hline Total & 77.28 & 120.00 & \\
\hline
\end{tabular}

1/ Mauritania's quota is SDR 64.4 million. 


\title{
ATtaChment I. \\ LETTER OF INTENT
}

Nouakchott, November 19, 2011

\author{
Madame Christine Lagarde \\ Managing Director \\ International Monetary Fund \\ 700, 19th Street, NW \\ Washington, DC 20431 \\ USA
}

Dear Madam Managing Director:

1. The government's efforts have continued to strengthen the macroeconomic fundamentals of Mauritania, enabling the country to register positive growth for a second consecutive year. Prudent policymaking and rising metals prices have helped foster an environment of macroeconomic stability, in spite of the sharp increases in energy prices. However, the economy remains vulnerable to exogenous shocks and faces a severe rain shortage this year, which could lead to a serious food crisis, comparable to the drought years Mauritania experienced in 200-03. The drought is likely to further impoverish rural areas that are already characterized by high rates of unemployment and poverty. The targeted short-term emergency program, which we intend to finance with our own budgetary resources, should mitigate the effects of the drought and help us react promptly to food insecurity risks.

2. To further entrench political pluralism and consolidate democracy, the government has embarked on a process of inclusive dialogue with the opposition parties, which led to a consensus on a number of political reforms. These reforms include modifying certain provisions of the constitution to rebalance the relationship between the executive and legislative branches and to ensure greater transparency of elections, notably through the creation of an independent structure in charge of organizing elections.

3. We have achieved the June 2011 objectives of the three-year ECF-supported arrangement. More precisely, we have met all the quantitative performance criteria for endJune 2011 (Table 1). In addition, the structural benchmarks (Table 2a) for end-June and September were all met, but with a slight delay for the publication of the decree on large industrial oil and gas consumers and the audits of commercial banks' financial statements. Concerning the end-October structural benchmark on the poverty and vulnerability survey, the preparations were completed on time, but the execution of the survey had to be postponed because of logistical difficulties and the overlap with the civil status survey. We expect to complete the poverty and vulnerability survey for Nouakchott by the end of the year and cover the rest of the country in 2012. 
4. This Letter of Intent (LOI) is based on the previous LOI and Memorandum of Economic and Financial Policies (MEFP) approved by the IMF's Executive Board on June 22, 2011. Our macroeconomic policy program will continue to balance our efforts to consolidate macroeconomic stability on the one hand, and the need to respond appropriately to the drought and elevated food prices on the other hand. We will also pursue our goals of bringing down unemployment and improving general living conditions. In order to achieve the objectives under the ECF-supported program, we are committed to continue implementing prudent, appropriate, and consistent macroeconomic policies. Furthermore, we have succeeded in mobilizing US\$2 billion in donor assistance, corresponding to over 64 percent of the total commitments made at the Brussels Round Table in 2010. As warranted by developments in food insecurity risks, we intend to call on the assistance of our bilateral and multilateral partners in an effort to mobilize the necessary additional assistance, particularly through emergency grants.

\section{Recent TRends In The ECONOMY AND The Program FOR 2011}

5. The economic recovery that started in 2010 gained momentum in 2011, reflecting continuing dynamism of the non-extractive industries (the production index of these industries was up by 16 percent year-on-year in the first six months of the year) and services. A prudent monetary policy stance helped contain inflation to 5.4 percent year-on-year at endJune despite rising international food prices. The current account deficit narrowed considerably as a result of rising export prices and strong external demand. Consequently, official reserves significantly exceeded the program target and stood at US\$426 million at end-June, the equivalent of 3.6 months of imports.

6. The most notable developments in the area of public finances in the first half of 2011 were the considerable increases in mining revenue, important improvements in tax collection, and the nonpayment of energy subsidies related to the delayed adoption of an advance decree. As a result, the net government surplus rose by 1.4 percentage points of GDP at end-June, notwithstanding the expenditures linked to the short-term temporary emergency program ("Programme de Solidarité"). The government's cash surplus reduced the need to issue T-bills.

7. Money supply rose by 25 percent year-on-year in the twelve months to June 2011. This increase was higher than anticipated by the program and is essentially attributable to a more substantial accumulation of foreign reserves. In contrast, private-sector credit growth was in line with program projections even after adjusting for the recapitalization of SOMELEC, the public electricity company, which was accompanied by a marked reduction in its bank loans. Banks saw their free reserves increase to very high levels. After appreciating at the beginning of the year, the ouguiya depreciated. The Central Bank of Mauritania (CBM) limited its interventions to smoothing excessive volatility in the exchange rate. 
8. The macroeconomic projections for the remainder of 2011 are broadly consistent with program objectives. Real GDP growth is expected to be 4.8 percent in 2011 , slightly below program projections, due to the drought-related downturn of the agricultural sector. Inflation is set to increase to about 6.7 percent year-on-year at end-December, reflecting a gradual liberalization of several administered prices. Official foreign exchange reserves, which attained a record level of US\$522 million at end-September 2011, are expected to stand at US $\$ 445$ million at the end of the year, following several interventions to provide resources to the foreign exchange market.

9. Maturing T-bills, the recent increase in the minimum wage, and the acceleration of investment and subsidy payments in the last two months of the year are not expected to significantly affect the Treasury's cash position. In fact, due to its comfortable cash reserves, the Treasury reduced its reliance on bank financing, resulting in a pronounced drop in T-bill rates to 2.75 percent at end-October and excess liquidity in the banking sector. However, banks' liquidity surplus has not translated into undue private-sector credit growth. The CBM remains vigilant and stands ready to act if a sharp increase in credit to the economy should generate inflationary pressures.

\section{Program for 2012}

10. Mauritania's overall economic outlook remains favorable for 2012, although significant challenges remain. GDP growth in 2012 is expected to be 5.5 percent thanks to the improved performance of the mining sector (particularly gold). On the other hand, cereal production is projected to decline by about 50 percent during the 2011/2012 agricultural season. The authorities' determination to react to any inflationary pressures should limit inflation to 6.8 percent in 2012. Increased production and high metals prices should help to offset to some extent the anticipated increase in food imports, limiting the deterioration in the current account deficit. The Mauritanian economy's capacity to withstand exogenous shocks will be strengthened by accumulating official reserves (which will reach the equivalent of 4.2 months of imports at end-2012) and saving a share of additional mining revenues.

\section{A. The macroeconomic program}

\section{Fiscal policy}

11. Fiscal policy in 2012 will aim at strengthening investment and social expenditure, implementing an emergency program to address the immediate impact of the drought, increasing non-mining tax revenue, and gradually phasing out non-targeted subsidies. The recently approved 43 percent increase in the minimum wage will affect only 4,000 employees in the public sector and will not have a significant impact on the budget. Consequently, the basic non-oil deficit is projected at approximately 0.7 percent of non-oil GDP in 2012, corresponding to a 0.3 percent of non-oil GDP improvement compared to this year. However, the overall deficit is deteriorating and remains high at 3.4 percent of non-oil 
GDP. Financing requirements will be largely met through nonbank financing and concessional budgetary assistance.

12. The revenue target has been set at 25.6 percent of non-oil GDP. Mining receipts account for a large share of all revenue, with a dividend pay-out ratio from SNIM set to at least 30 percent. The improvement in tax revenue will, among other things, accrue from restoring excises on tobacco (20 percent). In collaboration with an IMF TA mission scheduled for early 2012, we intend to review mining taxation and set up a mining fund.

13. In the 2012 budget, total government expenditure will be contained at UM 384 billion (30.2 percent of GDP). Planned expenditures incorporate a package of measures to ease the impact of the drought on the general public (distribution of free food, subsidies for essential goods, cash transfer mechanisms, and providing farmers and stockbreeders with animal feed and agricultural inputs at reduced prices). Current expenditure will be reduced to 20.3 percent of non-oil GDP through control of the wage bill and anticipated gains due to: (i) the exclusion of large industrial consumers from the administered petroleum product pricing structure and the elimination of the corrective margin with effect from January 2012; (ii) the increase in electricity prices for industrial consumers, which will be based on the findings of a study on electricity tariffs (see below); and (iii) the reduction in gas subsidies. Given our enhanced capacity to implement capital spending plans, we intend to substantially raise investment expenditure. As of 2012, we also plan to begin repay domestic arrears, including those related to tax credits. If fiscal revenue turns out to be weaker than expected, we stand ready to make necessary adjustment on the spending side, particularly to nonessential expenditure on goods and services.

\section{Monetary, financial, and foreign exchange policies}

14. The conduct of monetary policy will remain prudent and primarily focused on controlling inflation. The monetary objective is to increase broad money by 13.2 percent in 2012, which will support efforts to strengthen the private sector and meet financing needs of the non-extractive activities. However, the monetary authorities stand ready to react to any sign of inflationary pressures by tightening monetary policy, which includes raising reserve requirements if excess liquidity in the banking sector reveals itself to be structural in nature.

15. The CBM's independence will be reinforced by clearly identifying the amount of Tbills that need to be issued for monetary purposes. T-bills for monetary operations will be used to manage liquidity on a short-term basis, and the associated costs will be fully borne by the CBM. We also plan to improve liquidity management by organizing weekly meetings of the budget and monetary policy coordination committee, which will analyze the Treasury's cash position and make three-month rolling cash management forecasts. In an effort to develop flexible monetary policy instruments on a more permanent basis, we will benefit from the recommendations of the TA mission by the IMF's Monetary and Capital Markets Department (MCM) scheduled for early 2012. 
16. With respect to foreign exchange policy, the measure to limit bids for foreign exchange to 130 percent of the banks' free reserves has proven effective at reducing the amount of leveraged bids. Building on this success, we will ensure that the exchange rate market continues to be transparently and efficiently managed, including through conducting sales of foreign exchange solely through regular market sessions. The foreign exchange purchased at the auctions organized by the CBM will be delivered to the purchasing commercial bank by no later than the next day. The CBM will continue to refrain from any intervention that might distort the functioning of the market, and will limit its interventions to smoothing excessive exchange rate volatility.

17. The reform of the financial system will be accelerated with a view to deepening financial intermediation, strengthening safeguards, and addressing the constraints identified by Fund TA missions. The financial sector study that is currently being prepared by the World Bank will help us to set strategic priorities, including priorities for the microfinance sector. Most commercial banks already comply with the regulation that sets a floor of UM 5 billion for bank capital, and this floor will be raised to UM 6 billion in 2012. Our actions will focus on the following:

- Development of long-term savings. We will shortly adopt an instruction to lower the regulatory interest rate floor for a certain class of savings products, which will better enable banks to attract long-term deposits and reduce the maturity mismatch for longterm loans.

- $\quad$ Monitoring of risks. We are aware that the decline in T-bill rates will contribute to a reduction in banks' profitability. We intend to monitor banks' remedial strategies closely and develop an action plan for addressing financial sector instability if it should materialize. We will also allocate further resources to the credit bureau of the central bank [centrale des risques]. As a result, the credit bureau will have an adequate IT infrastructure, improve its capacity to maintain an individualized identification number for each borrower, provide timely information, and begin creating a database on borrowers in arrears. We are currently analyzing results of the recently completed audits of commercial banks (structural benchmark for endSeptember 2011) and we plan to complement these findings with an international audit of all banks, funded by the World Bank, to be completed by end-June 2012 .

- $\quad$ Strengthening of banking system regulations and supervision. The CBM, together with TA by AFRITAC West, will pursue their ongoing efforts to phase in a new capital adequacy framework (Basel II) and review the banking law in priority areas (appealing against CBM's penalties and money laundering). In the short term, the CBM will ensure that the banking supervision department has sufficient financial resources and can operate free of interference, while monitoring banks' compliance with existing prudential rules and regulations. Penalties for breach of reserve requirements, concentration limits, and foreign exchange exposure limits will be 
strictly applied. At the same time, the banking supervision department will ensure that on-site supervision is well organized and professionally run, with a strict and uniform application of the existing regulatory framework, notably through risk-based supervisory assessments. World Bank technical assistance will help support us in this area. We will also review the rules on connected lending practices, and begin our analysis by calculating the impact on the banking system of tightening the definition of connected parties (structural benchmark for end-March 2012).

- IFRS. The CBM will continue to make the necessary efforts, with technical assistance, to complete the remaining steps for IFRS adoption by end-2012. In the meantime, the CBM, with the assistance of an international audit firm, will quantify the differences between the CBM's 2010 financial statements prepared under Mauritanian accounting standards and IFRS by end-March 2012 (structural benchmark).

- $\quad$ Transparency. In June 2011, we published the CBM's 2010 financial statements and the auditors' opinion. The detailed and consolidated survey of the banking system will be published quarterly on the CBM's website in order to allow interested parties to review the status of the banking system. The CBM will continue to have its financial statements - including its reserves position - audited by an international auditing firm selected through an international bidding process.

\section{External sector and debt management}

18. Given the favorable outlook for production and metals prices (iron ore, gold, and copper), the current account deficit will be around 7 percent of GDP in 2012, with the increase relative to the preceding year caused by rising food imports and substantial investments in the energy sector. The deficit will be financed through higher external financing as well as through FDI in the mining and oil sectors.

19. To ensure external debt sustainability, we will mobilize concessional financing to finance our public investment program. A committee has been set up to prepare an external indebtedness strategy for end-December 2011 (structural benchmark), which will benefit from the assistance of an international expert and will take account of IMF and World Bank recommendations. The decree pertaining to this committee will be published by end-2011. We will actively pursue our best efforts to complete debt relief agreements with bilateral creditors, in particular with Kuwait. The goal is to reach an outcome for the treatment of this debt in the coming months that is comparable to agreements reached with Algeria and Libya

\section{B. Structural reforms}

20. We attach great importance to structural reforms that contribute to high growth, create jobs for young people, and reduce poverty. We have broadened the dialogue on these reforms. Technical and financial partners are now invited to meet with the Technical 
Monitoring Committee (CTS) on a quarterly basis to ensure better coordination on structural reforms.

\section{Strengthening the social protection system and gradual removal of subsidies}

21. To unify and strengthen the social protection system, while enabling it to play an effective role in supporting the poor and vulnerable, the government, with UNICEF support, has used the recommendations of the assessment study of existing social protection programs to develop a social protection strategy. Together with technical and financial partners, this strategy will be confirmed at the regional level and adopted by the government by end- 2011 .

22. Our policy focus is on gradually phasing out poorly-targeted subsidies, particularly in the energy sector. Similarly, the urgent need to prevent a worsening of food insecurity calls for an expeditious assessment of existing subsidy systems, the implementation of a reliable system for targeting at-risk populations, and a robust pricing mechanism for energy products. In this context, we have recently adopted a strategy on food security and will continue our information campaign to educate the public about the high budgetary cost of subsidies and explain our future strategy, which has the following features:

- Implement an automatic fuel pricing mechanism, which smoothes fluctuations in international prices, while reducing existing subsidy margins and simplifying the existing fuel price formula.

- $\quad$ Evaluate the dedicated shops of the emergency program (boutiques de solidarité) under the supervision of a steering committee which will be strengthened by including representatives from the Food Security Commission (CSA), the National Statistical Office, civil society, the World Food Program, and UNICEF, in addition to representatives of the ministries concerned. The findings of this evaluation will help analyze the impact of the solidarity program on the poor, ensure more effective geographic distribution of the dedicated shops, and reduce the list of subsidized products.

- $\quad$ Finalize the vulnerability and poverty survey for Nouakchott before the end of the year, and extending it to the entire country in 2012 (structural benchmark endApril 2012). We also plan to use the results of the World Food Program-CSA survey scheduled for December 2011 to identify communities that are likely to experience food insecurity. These communities could benefit from the free food distributions program in 2012, which will be financed by the budget.

- Implement targeted cash transfer schemes that build on pilot programs with proven effectiveness that have already been implemented on a small scale by technical and financial partners. Resources freed up by the energy price adjustments will allow for greater use of conditional transfer programs, such as school meal programs, food-forwork initiatives and support for pregnant women. 


\section{Public finance reforms}

23. The strategic public finance plan, which was prepared with assistance from the technical and financial partners (in particular the IMF and EU), will lead to an operational action plan and a timetable for implementation by end-2011. This plan will cover all reforms related to budget preparation, execution, supervision, and transparency.

\section{Improving revenue collection}

24. Enhanced off-site monitoring and improved capacity to cross-check data at the General Tax Directorate (DGI) has helped identify new taxpayers and generated substantial additional revenue. We will continue our efforts in this area by drawing on our plan to collect tax arrears, which was finalized at end-June (structural benchmark). The census of all taxpayers has already started and will be completed as planned by end-December. Once completed, the survey will facilitate the issuance of unique identification numbers to all taxpayers, including those not managed by the DGI (structural benchmark). We have set up a joint commission to address the issue of how to refund VAT credits, and we will prepare an action plan for the gradual elimination of the withholding-at-source practice for VAT. An IMF TA mission scheduled for early January will help us design a comprehensive framework for addressing these issues. Repayment of VAT refunds will start in 2012.

25. Customs reform is making steady progress and is on track for full adoption of the ASYCUDA++ system and the migration to the central server by end-2011 (structural benchmark). The transition to the new system will improve the management of exemptions and introduce digital archiving. To guard against tax evasion, the customs modernization strategy focuses on inspection and cross-checking of customs data against the data provided by SGS. We will strive to optimize our contract with SGS and streamline audits. Furthermore, we will install the SGS-Customs interface, provided that our capacities increase as planned, and monitor the implementation of a valuations database. To enhance synergies with the DGI and formalize information exchanges on taxpayers, a memorandum of understanding between the DGD and the DGI will be drawn up by December 2012. The draft of the new customs code is progressing well, and will be ready for submission to the Council of Ministers by end-January 2012 with the view to having it adopted by June 2012 .

\section{Managing public expenditure}

26. Improving decision making and active cash flow management are priorities for the government. The implementation of the Single Treasury Account, initially scheduled for end2011 (structural benchmark), has been largely completed after closing the Treasury's dispersed sub-accounts. All related measures, in particular the acceptance of the Treasury as a fully-fledged member of the clearing house, will be put into practice by November 2011. The Treasury/CBM interface began operating in August 2011 and will be fully functioning by March 2012. 
27. With respect to budget preparation and execution, we started to use the functional classification of public expenditure and itemized all subsidy expenditures previously included under the heading "common expenditures" (dépenses communes) in the 2012 budget. Mindful of the need to improve budget preparation and execution, the authorities will take all steps necessary to rehabilitate the budget process. We have regularized extrabudgetary expenditures of UM 16 billion, and we agree to resort to one-off spending procedures and cash advances and transfers only in cases of extreme urgency. We will ensure that the budget clearly specifies and spells out all transfers to public enterprises as well as any new tax levered on private companies. To evaluate the financial position of the government, we will produce a comprehensive inventory of domestic debt and government liabilities to public and private entities, including commercial banks (structural benchmark for end-March 2012). This inventory will be published and serve as a basis for settling the identified arrears.

28. In line with IMF TA and World Bank recommendations regarding the public expenditure review, we will step up our efforts to launch an integrated public financial management system, strengthen capacities for the internal and external review of public expenditure, and ensure that the new procurement code is fully implemented.

\section{Containing the wage bill and improving the quality of public services}

29. We will accelerate the civil service reform, which has been lagging considerably. In this context, we will use the current census of civil servants as a basis for the payroll (structural benchmark for end-June 2012). The public sector will continue to ban any recruitment that is not governed by civil service regulations. In the short term, we also plan to put in place an effective and permanent mechanism that controls for the presence of civil servants in their offices. To strengthen human resources management, we plan, with World Bank TA, to conduct an organizational audit, beginning with the Ministries of Education, Finance, and Health. Furthermore, a methodology for forecasting the wage bill will be designed and implemented at the Ministry of Finance with assistance from AFRITAC West. In particular, we intend to make the tracking of personnel expenditure more effective, and introduce forward-looking management of staffing levels. Allowances will be made for replacing departing personnel with a controlled number of new recruits, reflecting the qualitative needs of government.

\section{Improving public enterprise performance}

30. The government is committed to easing the budgetary burden associated with subsidy payments to public enterprises. To manage these transfers more effectively, we will carry out a technical and financial audit of MAURIPOST, SNDE, SOMAGAZ, and SONIMEX, which should be completed by end-2011 (structural benchmark). These audits, funded by the World Bank, should help prepare the process of mending these companies' financial position. Performance contracts will also help make their management more effective. We will also 
organize regular financial audits of public enterprises and improve coordination between the various ministries concerned. To improve the monitoring of the wage bill of public enterprises, we intend to carry out a personnel census, produce a centralized database at the level of the Directorate-General of Government Property, and review the government's wage payments to public enterprises more closely.

\section{Reforming the electricity sector}

31. Following the study on the restructuring of the electricity sector and SOMELEC, we recapitalized SOMELEC to the order of UM 20 billion. An additional capital increase of UM 13 billion will be paid by end-December 2011, with no impact on the government budget. At the same time, the government has begun paying its electricity bills to SOMELEC on time, and has paid SOMELEC a substantial part of the company's operating subsidy. This has enabled SOMELEC to limit its recourse to bank borrowing at high interest rates.

32. In an effort not to jeopardize the restructuring of SOMELEC, we will ensure that the electricity bills of all government agencies and public enterprises are paid regularly. We have clarified the net financial position between SOMELEC and the government, and envisage settling the associated arrears over a period of three years. A formal plan will be presented by end-December 2011 (structural benchmark). Furthermore, the tenders for the electricity tariff study have been received and processed, and the contract has been awarded. This study will review existing tariffs, in particular those applied to large industrial consumers, which will be revised upward as of July 2012 (structural benchmark). Such action will be part of the ongoing reform plan aimed at reducing technical and non technical losses, as well as reducing costs by moving to gas-powered facilities by $2014-15$.

\section{Improving the business climate and promoting the private sector}

33. We are committed to remedy the weaknesses in the investment climate and lifting the constraints on private-sector development. To this end, a new investment code has been prepared and is expected to be submitted to the Council of Ministers for approval in the near future. The new code provides for a one-stop facility that will simplify administrative procedures related to new investments. A national strategy for developing private-sector skills will also be introduced. The authorities have put additional emphasis on the measures aiming to modernize the education system such as vocational training programs for young graduates and the unemployed. We will also align existing curricula with private-sector needs. Moreover, we will mobilize additional resources to increase agricultural outputwhich remains below potential - through subsidization of fertilizers and seeds, the development of new irrigated fields, and the upgrading of infrastructure projects, such as dams.

34. Regarding measures to boost employment, we plan to start an employment study in January 2012 that will contribute to establish a reliable database on labor market conditions. In the meantime, we will implement an integration program for young unemployed 
university graduates. The goal is to help them develop their own businesses, especially in the agricultural sector. Moreover, this program will be extended to the fishing sector. Efforts will also be made to move the unemployed without an education into permanent jobs through income-generating activities (IGAs) in rural and urban areas. At the same time, with the technical and financial support of the World Bank, we intend to introduce a broad training and integration program focusing on unskilled workers.

\section{Strengthening governance and transparent management of public resources}

35. Fighting corruption is a government priority. We adopted a national anti-corruption strategy (SNLC) in 2010, aiming at ending impunity and limiting fiscal evasion, fraud, and poor management of public resources. The government is also committed to total transparency in the management of financial resources originating from the mining industries. To illustrate this commitment, Mauritania has been a member of the Extractive Industries Transparency Initiative (EITI) since 2005. A mission evaluating Mauritania's progress towards EITI principles visited Nouakchott in October, and we expect to become fully compliant by the end of this year. We have organized seminars on good governance in the extractive industries. Importantly, we propose to broaden the scope of this initiative to encompass new sectors, specifically fishing and the entire value chain of the extractive industries.

\section{Improving economic statistics}

36. We are mindful of the crucial role of reliable statistical information in the preparation, monitoring, and assessment of macroeconomic policies, PRSP implementation, and progress towards the MDGs. A committee will meet each month as of January 2012 to validate government finance data, strengthen reconciliation with national accounts, and carry out cross-checking with data received by the various line ministries. We intend to begin a survey that will eventually lead to a comprehensive reform of the CPI index (IHPC) in 2012, financed by our own budgetary resources. The price index will then cover the entire national territory. A new survey on household living conditions (EPCV) will make it possible to update employment and poverty data in 2012. We will continue with the organizational and institutional reform of the ONS. In the same vein, we will launch statistical functions in ministerial departments to improve data collection and processing for macroeconomic aggregates, national accounts, prices, and debt.

\section{Risks}

37. Although the Mauritanian economy is performing well, various risks may interfere with program objectives, including: (i) a greater-than-anticipated impact of the drought on the agriculture/stockbreeding sector; (ii) the return of large volatility in export prices (iron ore, copper, and gold) and erratic fluctuations in import prices (wheat, rice, and oil); and (iii) shortfalls in concessional external financing. The government stands ready to take 
appropriate measures to mitigate these risks, should they materialize. Any such corrective measures will be taken in consultation with IMF staff.

\section{Conclusion}

38. As the main objectives of the program for the first half of 2011 have been achieved (Tables 1 and $2 \mathrm{a}$ ), the government requests approval of the third review of the program supported by an arrangement under the ECF as well as the disbursement of SDR 11.04 million. While we do not seek modification of the end-December 2011 performance criteria, we believe that the more ambitious targets incorporated in the new macroeconomic framework are realistic and achievable. We have agreed to new performance criteria for endJune 2012 and indicative targets for end-December 2012.

39. We will maintain a close policy dialogue with the IMF and are prepared to take additional actions, if necessary, to achieve program objectives. We will continue to provide IMF staff with the information necessary for continuous program monitoring. New structural benchmarks have been set for end-2011 and 2012 (Table 2b). The fourth review under the program is scheduled to be concluded by June 1, 2012, and the fifth review by November 30 , 2012.

Very truly yours, $/ \mathrm{s} /$

Thiam Diombar

Minister of Finance

/s/

Sidi Ould Tah

Minister of Economic Affairs and Development

$/ \mathrm{s} /$

Sid' Ahmed Ould Raiss

Governor of the Central Bank of Mauritania 
Table 1. Mauritania: Quantitative Benchmarks and Performance Criteria for 2011 and 2012

the First Annual Program under the ECF Arrangement 1

(Cumulative change from end-December 2010 and from end-December 2011) $1 /$

\begin{tabular}{|c|c|c|c|c|c|c|c|c|c|c|c|c|}
\hline & \multicolumn{3}{|c|}{ End-Mar. 2011} & \multicolumn{3}{|c|}{ End-Jun. 2011} & \multirow{2}{*}{\multicolumn{2}{|c|}{$\begin{array}{cr}\text { End-Sep. } & \text { End-Dec. } \\
2011 & 2011 \\
\begin{array}{c}\text { Indicative Performance } \\
\text { Target }\end{array} & \text { criteria } \\
\end{array}$}} & \multirow{2}{*}{$\begin{array}{r}\begin{array}{c}\text { End-Mar. } \\
2012\end{array} \\
\begin{array}{c}\text { Indicative } \\
\text { Target }\end{array}\end{array}$} & \multirow{2}{*}{$\begin{array}{r}\begin{array}{r}\text { End-Jun. } \\
2012\end{array} \\
\text { rformance } \\
\text { criteria }\end{array}$} & \multirow{2}{*}{$\begin{array}{r}\text { End-Sep. } \\
2012 \\
\text { Indicative } \\
\text { Target }\end{array}$} & \multirow{2}{*}{$\begin{array}{r}\text { End-Dec. } \\
2012 \\
\text { Indicative } \\
\text { Target }\end{array}$} \\
\hline & $\begin{array}{r}\text { Indicative } \\
\text { Target }\end{array}$ & $\begin{array}{r}\text { Indicative } \\
\text { Target } \\
\text { adjusted }\end{array}$ & Actual & $\begin{array}{l}\text { Performance } \\
\text { criteria Rev. }\end{array}$ & $\begin{array}{r}\text { erformance } \\
\text { criteria } \\
\text { adjusted }\end{array}$ & Actual & & & & & & \\
\hline \multicolumn{13}{|l|}{ Quantitative targets } \\
\hline Net international reserves of the BCM (floor); in million of US $\$ 21$ & 4.4 & 14.3 & 33.4 & 46.9 & 29.5 & 100.8 & 233.0 & 82.9 & -6.9 & 41.8 & 76.1 & 37.7 \\
\hline Net domestic assets of the BCM (ceiling); in billions of ouguiyas $2 /$ & 4.7 & 2.1 & -7.8 & -8.4 & -3.8 & -9.6 & -7.9 & -7.5 & -3.1 & -13.6 & -14.9 & -0.8 \\
\hline Basic non-oil balance; in billions of ouguiya & -8.6 & -8.6 & 18.1 & 7.9 & 7.9 & 14.0 & 15.5 & -17.0 & -1.7 & 15.7 & 16.7 & -8.4 \\
\hline \multicolumn{13}{|l|}{$\begin{array}{l}\text { Contracting or guaranteeing of new medium- and long-term nonconcessional extermal debt with } \\
\text { maturities of one year or more by the govermment, BCM, or state-owned enterprises, excluding } \\
\text { SNIM (continuous quantitative performance criterion) (ceiling) } 3 /\end{array}$} \\
\hline $\begin{array}{l}\text { Contracting or guaranteeing of new nonconcessional external debt with an original maturity of } \\
\text { less than one year by the govermment, BCM, or state-owned enterprises, excluding SNIM } \\
\text { (continuous quantitative performance criterion) (ceiling) }\end{array}$ & 0 & & 0 & 0 & & 0 & 0 & 0 & 0 & 0 & 0 & 0 \\
\hline New external arrears on non reschedulable debt (continuous quantitative performance criterion ) & 0 & & 0 & 0 & & 0 & 0 & 0 & 0 & 0 & 0 & 0 \\
\hline Poverty-related expenditures; in billions of ouguiyas (indicative target) & 19.6 & & 5.8 & 32 & & 42.6 & 68.9 & 106.5 & 24.3 & 56.4 & 87.1 & 115.7 \\
\hline \multicolumn{13}{|l|}{ Adjustors (in millions of US\$) } \\
\hline Net international assistance & 6.9 & & 29.8 & 24.8 & & 10.0 & 31.1 & 32.8 & -7.2 & -39.0 & -41.5 & -50.0 \\
\hline Cumulative disbursements of official loans and grants in foreign currency & 13.9 & & 37.9 & 51 & & 38.3 & 64.1 & 92.6 & 0.0 & 0.0 & 4.7 & 28.1 \\
\hline Impact of any additional debt relief & 0 & & 0 & 0 & & 0 & 0 & 0 & 0 & 0 & 0 & 0 \\
\hline Cumulative amounts of external cash debt service payments & -7.0 & & -8.1 & -26.2 & & -28.3 & -33.0 & -59.8 & -7.2 & -39.0 & -46.2 & -78.2 \\
\hline FNRH contribution to the budget & 13.0 & & 0.0 & 22.5 & & 19.9 & 22.5 & 34.8 & 0.0 & 0.0 & 0.0 & 50.6 \\
\hline Cumulative disbursements of official grants in foreign currency & 13.7 & & 2.2 & 15.6 & & 2.5 & 15.6 & 24.6 & 0.0 & 0.0 & 4.7 & 14.0 \\
\hline $\begin{array}{l}\text { Memorandum item: } \\
\text { UM/\$ exchange rate (program) }\end{array}$ & 262 & & & & & & & 262 & & & & 262 \\
\hline
\end{tabular}

1/ For definitions, see Technical Memorandum of Understanding. Quantitative targets correspond to cumulative changes from the beginning of the relevant year.

3/ The higher ceiling for 2011 only accommodates the financing of a hybrid power plant. Ceiling for other nonconcessional borrowing is still zero. 
Table 2a. Mauritania. Structural Benchmarks, 2011

\begin{tabular}{|c|c|c|c|c|}
\hline Item & Measures & Date (end-of-period) & Outcome & Comment \\
\hline \multicolumn{5}{|c|}{ Tax administration } \\
\hline 1 & Finalize a plan for recovering tax arrears. & June 2011 & Met & A draft plan is already available and being used at the tax agency. \\
\hline 2 & Conduct a census of all businesses, including SMEs. & September 2011 & Met & $\begin{array}{l}\text { Some SMEs are now also being processed by the large taxpayer } \\
\text { unit. The Census has been completed. }\end{array}$ \\
\hline 3 & Fully implement and use ASYCUDA++ in major customs offices. & December 2011 & & $\begin{array}{l}\text { ASYCUDA++ is already installed in major customs offices. Full } \\
\text { implementation is expected by end-year. }\end{array}$ \\
\hline 4 & Issue, while surveys are underway, new identification numbers to taxpayers. & December 2011 & & $\begin{array}{l}\text { Numbers have already been distributed to all known taxpayers. } \\
\text { After the completion of the taxpayer census, numbers will also be } \\
\text { distributed to all taxpayers. A database will be sent to the Fund } \\
\text { once compiled. }\end{array}$ \\
\hline \multicolumn{5}{|c|}{ Expenditure policy } \\
\hline 5 & Modify petroleum price structure as defined in the TMU (TMU, paragraph 12). & June 2011 & $\begin{array}{l}\text { Met with slight } \\
\text { delay }\end{array}$ & Decree issued July 4, 2011. \\
\hline \multicolumn{5}{|c|}{ Public financial management } \\
\hline 6 & Introduce a Treasury Single Account. & December 2011 & & $\begin{array}{l}\text { Sub-accounts have been closed down. Accompanying measures } \\
\text { should be in place by November } 2011 .\end{array}$ \\
\hline 7 & Design an overall external debt management strategy. & December 2011 & & $\begin{array}{l}\text { An ad hoc committee has been set up to prepare a strategy with } \\
\text { the aid of an international consultant. }\end{array}$ \\
\hline 8 & $\begin{array}{l}\text { Complete a study on the financial situation of the main public enterprises, } \\
\text { following financial audits of the following enterprises: SOMELEC, SOMAGAZ, } \\
\text { SNDE, MAURIPOST, and SONIMEX }\end{array}$ & December 2011 & & $\begin{array}{l}\text { An audit of SOMELEC was completed in } 2010 \text {. The terms of } \\
\text { reference for the remaining four audits have been approved. The } \\
\text { bids are currently being processed. The World Bank is providing } \\
\text { financial assistance. }\end{array}$ \\
\hline 9 & $\begin{array}{l}\text { By end-December 2011, finalize a repayment strategy for the debt owed by the } \\
\text { government to SOMELEC over a period of three years. }\end{array}$ & December 2011 & & $\begin{array}{l}\text { The amount of the cross-debt has been determined. A general plan } \\
\text { for repayment of arrears will be prepared by end-2011. }\end{array}$ \\
\hline \multicolumn{5}{|c|}{ Central bank transparency } \\
\hline 10 & Audit the CBM's NIR and NDA data as of: end-December 2010. & March 2011 & Met & $\begin{array}{l}\text { End-December targets were audited by end-March. The completed } \\
\text { audit report was not provided until April } 2011 \text {. }\end{array}$ \\
\hline & end-June 2011 & September 2011 & Met & $\begin{array}{l}\text { The audit has been completed and the preliminary audit report has } \\
\text { been submitted on time. }\end{array}$ \\
\hline 11 & $\begin{array}{l}\text { The CBM should publish on its website audited financial statements together } \\
\text { with audit opinion for the year ended on December } 31,2010 \text {. }\end{array}$ & June 2011 & Met & \\
\hline \multicolumn{5}{|c|}{ Financial sector } \\
\hline 12 & $\begin{array}{l}\text { Conduct an audit of commercial banks' financial statements (as of end- } \\
\text { December 2010) by a firm hired through invitation to tender. }\end{array}$ & September 2011 & Met, with delay & $\begin{array}{l}\text { Staff received most audits on time, and the final two were sent via } \\
\text { mail in early November. }\end{array}$ \\
\hline 13 & Increase banks' minimum capital to UM 5 billion (US $\$ 18$ million). & December 2011 & & $\begin{array}{l}\text { Ongoing. All but two banks already met the } 2011 \text { threshold at the } \\
\text { end of } 2010 \text {. }\end{array}$ \\
\hline \multicolumn{5}{|c|}{ Social policy } \\
\hline 14 & $\begin{array}{l}\text { Conduct with the support of the World Food Program a vilnerability and poverty } \\
\text { survey. }\end{array}$ & October 2011 & Deferred to 2012 & $\begin{array}{l}\text { The poverty survey will be conducted in two phases. The } \\
\text { Nouakchott phase will be carried out before end-year, while the } \\
\text { survey for the rest of the country has been deferred until early } \\
2012 \text {. }\end{array}$ \\
\hline
\end{tabular}


Table 2b. Mauritania: New Structural Benchmarks under the ECF, 2011-12.

\begin{tabular}{|c|c|c|c|}
\hline Item & Measure & Date (end-of-period) & Objective \\
\hline \multicolumn{4}{|c|}{ Expenditure policy } \\
\hline 1 & Update the payroll file with actual results from the census of employees. & June 2012 & Control public wage bill. \\
\hline 2 & $\begin{array}{l}\text { Review electricity tariffs, including an increase for large consumers, based on } \\
\text { the results of the tariff study. }\end{array}$ & July 2012 & Phase-out poorly targeted subsidies. \\
\hline \multicolumn{4}{|c|}{ Public financial management } \\
\hline 3 & $\begin{array}{l}\text { Conduct an inventory of all domestic debt and formulate a plan to settle all } \\
\text { domestic arrears. }\end{array}$ & March 2012 & Enhance transparency of government financial operations. \\
\hline \multicolumn{4}{|c|}{ Central bank transparency } \\
\hline 4 & $\begin{array}{l}\text { Complete the report on the quantification of differences between the CBM's } 2010 \\
\text { financial statements prepared under national accounting principles and under } \\
\text { IFRS, prepared with the assistance of an international audit firm. }\end{array}$ & March 2012 & Enhance central bank transparency. \\
\hline 5 & $\begin{array}{l}\text { The CBM should publish on its website audited financial statements together } \\
\text { with audit opinion for the year ended on December } 31,2011 \text {. }\end{array}$ & June 2012 & \\
\hline 6 & Audit the CBM's NIR and NDA data as of end-December 2011. & March 2012 & \\
\hline \multicolumn{4}{|c|}{ Financial sector } \\
\hline 7 & $\begin{array}{l}\text { Review the rules on connected lending practices and calculate the impact on } \\
\text { banks of a tightening in the definition of connected parties. }\end{array}$ & March 2012 & Safeguard financial sector stability. \\
\hline \multicolumn{4}{|c|}{ Social Policy } \\
\hline 8 & Assess effectiveness of the dedicated shops used in the solidarity program. & December 2011 & $\begin{array}{l}\text { Improve targeting of next emergency program to better protect the } \\
\text { vulnerable and poor. }\end{array}$ \\
\hline 9 & $\begin{array}{l}\text { Conduct with the support of the World Food Program a vulnerability and poverty } \\
\text { survey. }\end{array}$ & April 2012 & $\begin{array}{l}\text { The poverty survey will be conducted in two phases. The } \\
\text { Nouakchott phase will be carried out before end-year, while the } \\
\text { survey for the rest of the country has been deferred until early } \\
2012 \text {. }\end{array}$ \\
\hline
\end{tabular}




\section{Attachment II. TeChnical Memorandum of Understanding}

1. This memorandum sets out the definitions of the quantitative targets for the period January 1, 2010-December 31, 2012, which are set forth in the Letter of intention (LOI) and reported in Table 1. It also establishes the content and frequency of the data to be provided to IMF staff for monitoring the program. For the purpose of this memorandum, the government is defined to include only the central government.

2. The quantitative targets are defined as ceilings or floors for cumulative changes between the reference periods described in Table 1 and the end of the month indicated.

\section{DEFINITIONS}

\section{A. Performance Criteria and Quantitative Benchmarks}

3. Net international reserves (NIR) of the Central Bank of Mauritania (CBM) are defined as the difference between the reserve assets of the CBM (i.e., the external assets that are readily available to, and controlled by, the CBM, as per the $5^{\text {th }}$ edition of the IMF Balance of Payments Manual) minus the foreign exchange liabilities of the CBM to residents and nonresidents. The gold holdings will be evaluated at the gold price in effect on November 30, 2009 (US\$1,127 per oz.) and the U.S. dollar value of reserves assets (other than gold) and foreign exchange liabilities will be calculated using program exchange rates, namely, the November 30, 2009 exchange rates between the U.S. dollar and the ouguiya (UM/US\$262.0), the SDR (US\$/SDR 1.61), the euro (Euro/US\$1.49), and other non-dollar currencies as published in the IFS.

4. Net domestic assets (NDA) of the CBM are defined as reserve money minus net foreign assets (NFA) of the CBM. Reserve money comprises: (a) currency in circulation (currency outside banks and commercial banks' cash in vaults); and (b) deposits of commercial banks at the CBM. NFA are defined as gross foreign assets of the CBM, including the external assets not included in the reserve assets, minus all foreign liabilities of the CBM (i.e., NDA = Reserve Money - NFA, based on the CBM balance sheet). NFA will be measured at the program exchange rates as described in Paragraph 3.

5. Government balance is defined for program monitoring purposes as non-oil central government basic balance excluding grants, which is equal to non-oil government revenue (excluding grants) minus government expenditure (excluding foreign-financed investment expenditure and interest due on external debt). The government balance will be measured based on Treasury data. Revenue are defined in accordance with the Government Financial Statistics manual (GFSM 2001), excluding the revenue related to oil- and other hydrocarbonrelated activities and transfers from the National Hydrocarbon Revenue Fund (FNRH) to the budget. They will be monitored on a cash basis (revenue recorded by Treasury). Expenditure will be monitored on the basis of payment orders, including the interest on domestic debt 
(paid by the Treasury or automatically debited from the treasury account at the CBM, including but not limited to discounts on treasury bills held by banks and nonbanks and interest charges on the consolidated debt of the government vis-à-vis the CBM).

\section{The new medium- and long-term nonconcessional external debt contracted or}

guaranteed by the government, the CBM, and State Owned Enterprises (excluding SNIM) is defined as debt to non-residents, with maturities of one year or longer, contracted or guaranteed by the government or the CBM with a grant element (defined as 1 minus the NPV-to-face value ratio, and estimated on the basis of the currency and maturity specific discount rates reported by the OECD (commercial interest reference rates) of less than 35 percent. This definition applies not only to debt as defined in point No. 9 of the Guidelines on Performance Criteria with Respect to Foreign Debt (IMF Executive Board Decision No 6230- (79/140), Point 9, as revised on August 31, 2009, and effective December 1, 2009 (Decision No.14416-(09/91); see Annex) but also to commitments contracted or guaranteed for which value has not been received. The national industrial and mining company (SNIM) is excluded from the ceiling on medium- and long-term nonconcessional external debt because the firm does not pose fiscal risks and can borrow without government guarantee.

\section{For program purposes, a debt is concessional if it includes a grant element of at}

least 35 percent, calculated as follows: the grant element of a debt is the difference between the present value (PV) of debt and its nominal value, expressed as a percentage of the nominal value of the debt. The PV of debt at the time of its contracting is calculated by discounting the future stream of payments of debt service due on this debt. The discount rates used for this purpose are the currency specific commercial interest reference rates (CIRRs), published by the Organization for Economic Cooperation Development (OECD). For debt with a maturity of at least 15 years, the ten-year average CIRR will be used to calculate the PV of debt and, hence, its grant element. For debt with a maturity of less than 15 years, the six-month average CIRR will be used. To both the ten-year and six-month averages, the same margins for differing repayment periods as those used by the OECD need to be added ( 0.75 percent for repayment periods of less than 15 years, 1 percent for 15 to 19 years, 1.15 percent for 20 to 29 years, and 1.25 percent for 30 years or more). The calculation of concessionality will take into account all aspects of the loan agreement, including maturity, grace period, payment schedule, upfront commissions, and management fees.

8. The short-term non-concessional debt is defined as the stock of debt with nonresidents, with original maturity of less than one year, contracted or guaranteed by the government or the CBM. This definition applies to debt as defined in point No. 9 of the Guidelines on Performance Criteria with Respect to Foreign Debt (Decision No. 12274-(00/85) August 24, 2000; see Annex). This definition excludes foreign currency deposits with the CBM. It also excludes normal import-related credits. 
9. External payments arrears are defined as overdue payments (principal or interest) on the external debt contracted or guaranteed by the government or the CBM after the expiration of the applicable grace period.

10. Treasury float (outstanding payments at the Treasury) is defined as the outstanding stock of payment orders registered at the Treasury and not yet executed by the Treasury. Once the RACHAD payment module is implemented, the float will be defined as the payment orders validated by the RACHAD payment module and not yet executed by the Treasury.

11. Poverty reduction expenditures will be estimated on the basis of the public expenditure functional classification based on the recommendations of the January 2006 technical assistance mission report of the IMF Fiscal Affairs Department ("Les réformes en cours de la gestion budgétaire et financière," March 2006). This estimate will only take into account domestically-financed expenditures.

\section{B. Structural Benchmarks}

\section{Structural benchmarks for the 2011 tranche of the program are:}

- $\quad$ Complete by end-December 2011 the issuance of new taxpayer identification numbers. This benchmark aims at building a centralized taxpayers database and provide each taxpayer with a single identification number. Observance of this benchmark will require transmission to IMF staff by end-December 2011 of the database, including all taxpayers and their single identification number.

- $\quad$ Full implementation and use of ASYCUDA++ in major customs offices by endDecember 2011.

- $\quad$ Introduction of a Treasury Single Account by end-December 2011.

- Design by end-December 2011 an overall external debt management strategy.

- Increase by end-December 2011 bank minimum capital to UM 5 billion (US\$18 million).

- $\quad$ Complete by end-December 2011 the study on the financial situation of major public enterprises. This will be based on the financial audit of the following companies: SOMELEC, SOMAGAZ, SNDE, MAURIPOST and SONIMEX.

- $\quad$ Complete by end-December 2011 a government arrears repayment plan for SOMELEC. 
- Assess effectiveness of the dedicated shops used in the solidarity program by endDecember 2011.

13. Structural benchmarks for the 2012 tranche of the program are:

- $\quad$ Conduct an inventory of all domestic debt and formulate a plan to settle all domestic arrears by end-March 2012.

- $\quad$ Audit the CBM's NIR and NDA data as of end-December 2011 by end-March 2012.

- $\quad$ Complete by end-March 2012 the report quantifying the differences between the CBM's 2010 financial statements under national accounting principles with those under IFRS, prepared with the assistance of an international audit firm.

- Review the rules on connected lending practices and calculate the impact on banks of a tightening in the definition of connected parties by end-March 2012 .

- $\quad$ Conduct by end-April 2012, with assistance from the World Food Program, a poverty and vulnerability survey.

- $\quad$ Publish on the CBM's website the audited financial statements together with audit opinion for the year ended on December 31, 2011 by end-June 2012.

- Update the payroll file with actual results from the census of employees by endJune 2012.

- $\quad$ Review electricity tariffs, including an increase for large consumers, based on the results of the tariff study by end-July 2012 .

\section{Program Adjustors}

14. NIR and NDA targets are derived based on the projected amounts of the FNRH contribution to the budget and of the net international assistance. The latter is defined as the difference between (a) the sum of cumulative disbursements of official loans and grants (budget support; excluding HIPC assistance and project-related loans and grants) in foreign currency and of the impact of any additional debt relief obtained after June 30, 2006; and (b) the total amount of external cash debt service payments (including interest on foreign liabilities of the CBM).

\section{In case net international assistance or the contribution of the FNRH to the}

budget falls short of the amounts projected in Table 1, the floor for NIR will be adjusted downward and the ceiling on NDA will be adjusted upward by an amount equivalent to the difference between the actual levels and the projected levels. In the case of the NDA ceiling, this amount will be converted into ouguiya at the program exchange rates. The cumulative 
downward adjustments to NIR will be limited to US\$35 million. The cumulative upward adjustments to NDA will be limited to the ouguiya equivalent of US\$35 million at program exchange rates. In case the contribution of the FNRH to the budget exceeds the amounts projected in Table 1, the floor for NIR will be adjusted upward and the ceiling on NDA will be adjusted downward by an amount equivalent to the difference between the actual levels and the projected levels.

16. The floor on the basic non-oil deficit will be adjusted upward - that is, the maximum deficit will be increased for any higher than programmed disbursement of budgetary grants.

\section{REPORTING REQUIREMENTS}

17. To allow for the monitoring of economic developments and program performance, the Mauritanian authorities will provide the IMF with the following specific information.

\section{Central Bank of Mauritania (CBM)}

- The monthly balance sheet of the CBM, and monthly data on (a) CBM's gross foreign exchange reserves (at program exchange rates and at actual official exchange rates); and (b) the FNRH (National Hydrocarbon Revenue Fund) balances, as well as receipts and outlays (transfers to the Treasury account) and their timing, within two (2) weeks following the end of each month.

- The monthly monetary survey, the aggregated balance sheet of the commercial banks, and monthly data on foreign exchange positions of individual commercial banks by currency and on a consolidated basis at actual official exchange rates within three (3) weeks from the end of each month.

- Data on Treasury bills auctions and the new stock outstanding within a week following each auction.

- Monthly data on the level of liabilities of each public enterprise to the banking sector, within one month from the end of each month.

- Monthly external debt data within 30 days at the end of each month, following the monthly meeting of the technical debt committee, the minutes of which will be attached. This information shall include:

- The external debt data file: service of the external debt of the CBM, government, and SNIM, including changes in arrears and rescheduling operations, debt service due and paid in cash, HIPC relief granted by multilateral and bilateral creditors and the amount of HIPC relief provided to Mauritania in the form of grants. 
- The monthly list of medium- and long-term public or publicly-guaranteed external loans contracted during each month, identifying for each loan: the creditor, the borrower, the amount and currency, the maturity and grace period, interest rate arrangements and commissions. The list must also include any loans currently being negotiated.

- Quarterly complete balance of payments and data on the outstanding stock of external debt (by creditor, by debtor, and by currency) within 30 days following the end of each quarter.

- Bi-monthly table projecting foreign exchange flows and flows of monetary liquidity within one week.

\section{Ministry of Finance}

- The Treasury's monthly cash and liquidity management plan, updated by the fiscal and monetary policy coordination committee, will be reported on a monthly basis along with the minutes of the weekly meetings.

- Monthly Treasury data on budget operations, revenues (including transfers from the FNRH), expenditures, and financing items, data on operations of special accounts, data on the execution of the domestically-financed part of the investment budget (including the data on capital spending, spending on goods and services, and salaries included in the investment budget), and Customs and Tax Departments monthly revenue collection reports (Rapports mensuels des recettes) within two (2) weeks following the end of each month.

- Monthly data reconciled between the Treasury and the Budget Directorate on the execution of expenditure on wages, including the breakdown of civil service base pay and back pay, wages for which payment has been authorized or is pending authorization for diplomatic missions, the military, the police, the national guard, and public institutions.

- Monthly data on the execution of the foreign-financed part of the investment budget based on the summary presentation included in the Consolidated Investment Budget document (Budget consolidé d'investissement) and data on foreign grants and loans received by government, its agencies, and by public enterprises by donor or creditor and by currency of disbursement within two (2) weeks following the end of each month.

- Monthly reports on oil- and other hydrocarbon-related production and financial flows, including data on oil sales and repartition of oil revenue among all partners involved in oil production within one (1) month from the end of each month. 
- Annual balance sheets audited or certified by a statutory auditor of the accounts of public enterprises and autonomous public institutions.

- Quarterly data on the operations of oil sector enterprises and on those in the mining sector.

\section{National Statistical Office}

- Monthly consumer price index within two (2) weeks following the end of each month.

- Quarterly industrial production index within one (1) month of the end of each quarter.

- Quarterly note on economic activity and international trade.

\section{Technical Monitoring Committee}

18. Monthly report on program execution three (3) weeks at the latest after the expiration of the month.

19. All data will be transmitted electronically. Any revisions to previously reported data accompanied by an explanatory note shall be promptly communicated to the staff.

\section{Central Government Operations Table}

20. The Treasury will prepare a monthly budget execution report in the format of a Central Government Operations Table (TOFE). In preparing this table, the following definitions shall be used:

- Grants are defined as a sum of foreign project grants (grants used in the execution of the foreign-financed investment projects included in the central government and the EPA parts of the consolidated investment budget and (parties $B E$ et $B A$ )); and foreign program grants for budget support including the multilateral HIPC debt relief on the government external debt budget and HIPC debt relief on the external debt of CBM and SNIM (including the part of the AFD/BFD debt relief on Cologne terms).

- Domestic bank financing of the government deficit is defined as a change in the net credit to the government from the banking system, defined as claims on the government minus deposits of the government with the banking system (including the HIPC account but excluding the deposits of public establishments and other administrative units $(E P A)$ with the CBM).

- Domestic nonbank financing of the government deficit is defined as a net change in holdings of Treasury bills by nonbanks. 
- Domestic arrears are defined as a net change in the Treasury float and in the stock of domestic claims (beyond a period of three months) on government acknowledged by the Ministry of Finance (including but not limited to accumulated payment arrears to public enterprises (utilities), international organizations, procurement contracts, and court orders).

- External financing is defined as the sum of the net outflows from (i.e., the opposite of the change in the balance of the FNRH's offshore account); net disbursements of foreign loans; and exceptional financing. The latter comprises (a) the accumulation of technical arrears and passive debts as defined in Paragraph 8; and (b) debt relief obtained on external government debt net of the HIPC assistance that is treated as grants. 


\section{ANNEX \\ Definition OF Debt Set Forth in No. 9 OF THE GUIDELINES}

The definition of debt set forth in No. 9 of the Guidelines on Performance Criteria with Respect to Foreign Debt reads as follows:

(a) For the purpose of this guideline, the term "debt" will be understood to mean a current, i.e., not contingent, liability, created under a contractual arrangement through the provision of value in the form of assets (including currency) or services, and which requires the obligor to make one or more payments in the form of assets (including currency) or services, at some future point(s) in time; these payments will discharge the principal and/or interest liabilities incurred under the contract. Debt can take a number of forms, the primary ones being as follows: (i) loans, i.e., advances on money to the obligor by the lender made on the basis of an undertaking that the obligor will repay the funds in the future (including deposits, bonds, debentures, commercial loans, and buyers' creditors) and temporary exchanges of assets that are equivalent to fully collateralized loans under which the obligor is required to repay the funds, and usually pay interest, by repurchasing the collateral from the buyer in the future (such as repurchase agreements and official swap arrangements); (ii) suppliers' credits, i.e., contracts where the supplier permits the obligor to defer payments until sometime after the date on which the goods are delivered or services are provided; and (iii) leases, i.e., arrangements under which property is provided which the lessee has the right to use for one or more specified period(s) of time that are usually shorter than the total expected service life of the property, while the lesser retains the title to the property. For the purpose of the guideline, the debt is the present value (at the inception of the lease) of all lease payments expected to be made during the period of the agreement excluding those payments that cover the operation, repair or maintenance of the property.

(b) Under the definition of debt set out in point 9 (a) above, arrears, penalties, and judicially awarded damages arising from the failure to make payment under a contractual obligation that constitutes debt. Failure to make payments on an obligation that is not considered debt under this definition (e.g., payment on delivery) will not give rise to debt. 
December 12, 2011

\section{IMF Executive Board Completes Third Review Under Mauritania's Extended Credit Facility Arrangement and Approves US\$17.1 Million Disbursement}

The Executive Board of the International Monetary Fund (IMF) completed today the third review of Mauritania's economic performance under the program supported by an Extended Credit Facility arrangement (ECF). ${ }^{1}$ The Board's decision, which was taken on a lapse of time basis, ${ }^{2}$ enables the immediate disbursement of an amount equivalent to SDR 11.04 million (US\$17.1 million), bringing total disbursements under the arrangement to an amount equivalent to SDR 44.16 million (US\$68.4 million).

The Executive Board approved a three-year arrangement for Mauritania in March 2010 for an amount equivalent to SDR 77.28 million (about 120 percent of the country's quota in the IMF, see Press Release No. 10/89).

Mauritania's macroeconomic performance continues to be strong, despite high international fuel and food prices and a severe drought. Economic activity has been resilient, inflation has been contained, and the fiscal and external positions have improved, creating space for a surge in reserves and a record decline in government borrowing.

\footnotetext{
${ }^{1}$ The Extended Credit Facility (ECF) has replaced the Poverty Reduction and Growth Facility (PRGF) as the Fund's main tool for medium-term financial support to low-income countries by providing a higher level of access to financing, more concessional terms, enhanced flexibility in program design features, and more focused streamlined conditionality. Financing under the ECF carries a zero interest rate, with a grace period of 51/2 years, and a final maturity of 10 years (http://www.imf.org/external/np/exr/facts/ecf.htm). The Fund reviews the level of interest rates for all concessional facilities every two years.

${ }^{2}$ The Executive Board takes decisions under its lapse of time procedure when it is agreed by the Board that a proposal can be considered without convening formal discussions.
} 
However, significant challenges remain. The outlook for 2012 is highly vulnerable to a sharp fall in external demand or a more severe than expected drought impact, which may require additional external assistance. Moreover, growth is still not sufficiently broad-based to reduce unemployment and poverty, especially in rural areas, where both remain high.

Continued fiscal consolidation is necessary to limit vulnerabilities and maintain macroeconomic stability. The draft 2012 budget appropriately preserves fiscal discipline while allowing for drought relief expenditures and protecting much needed investment spending. Decisive actions on subsidy and civil service reform as well as greater revenue mobilization are essential for creating much needed fiscal space and reducing fiscal policy's reliance on volatile mining revenues. Reaching agreement on outstanding debt relief is critical for preserving debt sustainability.

Continued satisfactory program implementation - including through the introduction of welltargeted social safety nets, effective implementation of the new investment and procurement codes, and reinvigorating labor market and public enterprise reforms - will help secure broad-based inclusive growth, improve employment, and reduce poverty. 